\title{
Napoleon w polskich lożach masońskich
}

Krzysztof Ostrowski 
nAPIS Seria XIII 2007

\section{Krzysztof Ostrowski}

\section{Napoleon w polskich lożach masońskich}

$\mathrm{B}$ rak jest dowodów osobistego udziału Napoleona w rytuałach lóż masońskich. Różni autorzy, międ zy innymi François Collaveri, Jean Morvan czy baron Comeau, rozważają możliwe daty dopuszczenia Napoleona do tajemnic związku: od 1785 roku w Valence, poprzez Nancy w 1797 roku, kampanię w Egipcie, aż do czerwca 1805, czyli do czasów Cesarstwa.

Jednak formalne przyjęcie Napoleona do którejś z lóż nie wydaje się istotne, gdyż jego zainteresowania i bezpośredni wpływ na rozwój wolnomularstwa przejawiły się inaczej. Po pierwsze, najbliższa rodzina i wspólpracownicy to czynni wolnomularze, piastujący wysokie urzędy w lożach, niewątpliwic za wiedzą i aprobatą Napolcona. Po drugie, głoszony w lożach kult Napoleona stal się wyrazistą cechą Cesarstwa w wielu krajach objętych jego kontrolą lub wpływem, co także wymagało aprobaty i zainteresowania samego Cesarza.

Bracia Cesarza: Józef, Ludwik, Hieronim i Lucjan, siostra Eliza i cesarzowa Józefina aktywnie działają w lożach, a dwaj pierwsi kierują Wielkim Wschodem Francji jako Wielki Mistrz i jego Namiestnik. Potężni urzędnicy Cesarstwa: Cambacérès, Lebrun, Fouchet, Maret, Champagny to również czynni wolnomularze, a wśród wojskowych doliczyć się można jedenastu marszałków Francji (w tym Kellerman, Murat, Masséna, Lefevbres, Soult, Lannes i Poniatowski).

Od chwili koronacji w 1804 roku Napoleon staje się jednym z podmiotów rytuału w setkach lóż we Francji i krajach sprzymierzonych z Francją. Wyrażany od początków wolnomularstwa szacunek dla Króla/Władcy, nadszarpnięty czasami Rewolucji, znalazł w osobie Cesarza idealny obiekt nowego kultu, chętnie podsycanego przez protagonistów władcy.

Rytuał lóz, oparty na symboliczuych ceremoniach, w znacznej mierze wykorzystywał słowo, tak mówione, jak i śpiewane. W okolicznościowych mowach, toastach, re- 
cytacjach i pieśniach lat 1805-1815 w różnych zakątkach Europy i w różnych językach pojawia się nawiązanie do Napoleona.

Tak też było i w lożach działających na rozdzielonych zaborami ziemiach Rzeczpospolitej. Loże prowadzące rytual po francusku lub po niemiecku stopniowo wprowadzają język polski, i tak w pierwszych latach XIX wieku, a może i wcześniej, pojawia się polska poezja masońska. Utwory, często oparte na obcych wzorach i zawsze służące celom wolnomularskiego obrządku, nie przedstawiają szczególnej wartości, ale dobrze wpisują się w nurt literatury okolicznościowej i użytkowej.

Podejmując przed pięćdziesięciu laty studia polonistyczne na Uniwersytecie Warszawskim, szybko zetknąlem się z interesującymi badaniami literatury okolicznościowej. W pięć lat później, w 1962 roku, pod kierunkiem profesora Zdzisława Libery przygotowałem pracę magisterską o polskiej poezji masońskiej'. Udało mi się odnaleźć i opracować dwieście utworów w języku polskim. a także zgromadzić materiał do porównań z poezją francuską i niemiecką. Praca po obronie zostala skierowana do archiwum, a moje zainteresowania badawcze przesunęly się w stronę socjologii i nauk politycznych.

Przystępując w 1999 roku do organizacji Ośrodka Studiów Epoki Napoleońskiej w Akademii Humanistycznej w Pultusku, myślałem przede wszystkim o współczesnych warunkach integracji europejskiej i jej dwustuletnich korzeniach, ale pamiętałem też o literaturze po rozbiorach, skąpych śladach kultu Napoleona w polskiej poezji masońskiej i interesujących przeobrażeniach tej poezji u schylku epoki. Miałem nadzieję, iż w ramach prac Ośrodka twórczość literacka związana z Napoleonem znajdzie swoje miejsce, szczególnie przy okazji dwustulecia kampanii 1806-1807 i powstania Księstwa Warszawskiego.

Pięknie opracowany w 1977 roku zbiór Andrzeja Zielińskiego² ulotnej poezji patriotycznej wojen napoleonískich trafnie przybliżył okolicznościowe utwory epoki, ale calkowicie pominąl - zapewne nie bez udziału cenzury — wątki wolnomularskie. Wydana w 1995 roku cenna praca Elżbiety Wichrowskiej jest pierwszą drukowaną antologią poezji masońskiej, ale nie przyniosła nieznanych mi wcześniej utworów związanych z Napoleonem.

Konferencja Cień zlotych skrzydet stwarza możliwość przypomnienia masońskich wątków w okolicznościowej literaturze epoki napoleońskiej i utworów znanych mi od lat sześćdziesiątych. W aneksie załączam obszerne fragmenty mojej pracy magisterskiej mające odniesienia do epoki napoleońskiej i działalności lóż wolnomularskich. Mam nadzicję, iż mimo niewątpliwych uproszczeń i niedoskonalości pracy studenckiej przy-

K. M. Ostrowski, Pol:ka poczja masoniska. Warszawa 1962, maszynopis w Archiwum Uniwersytetu Warszawskiego, $155 \mathrm{~s} .+220$ kart bibliograficznych.

A. Zieliński, Llotna poezja patriot)ezHa wojen mapoleonskich (1805-1814), Wrocław 1977.

'E. Wichrowska, Anologia poezii indatugkich Warszawad993. 
toczone fragmenty stanowią przykład zainteresowań w połowie XX wieku masońską literaturą okolicznościową epoki Oświecenia.

Przedstawiając w pracy charakter poezji masońskiej przywołuję tekst toastı za zdrowie Napoleona zachowanego w Archiwum Publicznym Potockich't:

za zdrowie Napoleona Wielkiego Cesarza Francuzów, Króla Whoskiego, Protektora Ligi Reńskiej. Czują serca nasze, co mu winna ludzkość, co ziemia polska, co zakon wolnomularski. Zlóżmy hołd podziwienia największemu z ludzi i połączmy życzenia, ażeby Wielki Świata Budownik błogosławił zawsze związkowi oręża jego.

Po takim toaście powinna rozbrzmiewać stosowna pieśń, a jej pierwszym polskim przykładem jest anonimowy utwór śpiewany w loży Świątynia Mądrości w Warszawie w grudniu 1806 rokư $^{5}$, kilkanaście miesięcy po podjęciu prac loży w języku polskim i zapewne kilka dni po przybyciu Cesarza do stolicy:

Co za Opatrzność nad nami!

Ojczyzna ma być dźwigniona!

Witajmy czulości łzami

WIELKIEGO NAPOLEONA!

Dıni szczęśliwe odtąd liczem,

Jak Stworzyciela rzekł słowy

„Lat dwanaście byłaś niczem,

Polsko, nadam Ci byt nowy". [...]

Złóżmy mu wdzięczności pienia,

Niech żyje Polski obrona,

Niech czczą późne pokolenia

WIELKIEGO NAPOLEONA!

W kilka miesięcy później w tej samej loży brat Jan Drozdowski, komediopisarz i tłumacz wolterowskiej Meropy, żegna oddziały polskie wyruszające z Wielką Armią utworem Pożcgnanie BB. Wojskow'ych, gdy pienuszy raz u'ychodzili z Ojczyzny do Francji $5807(1807 \mathrm{rok} u)^{\mathrm{h}}$

Marsz, marsz, ziomkowie, kamraci,

W którekolwiek pójdziem kraje [...]

+ K. M. Ostrowski, op. cit., s. 27.

5 Ibidem, s. 71 i karta 25.

"Ibidem, s. 71 i karta 78. 
Pod wielkim Napoleonem

Uczmy się, jak znosić znoje,

Kochać sławę, gardzić zgonem

I ogniska bronić swoje.

Tak loża Świątynia Mądrości żegnała przyszłych bolnaterów spod Somosierry...

Trzecim znanym dziś utworem odwołującym się bezpośrednio do Napoleona jest utwór Marcina Molskiego, wykonany w 1810 roku w loży Polaków Zjednoczonycl (darzącej Napoleona szczególna atencją) w rocznicę Konstytucji Trzeciego Maja':

Gdy narodowe wymazal święto

Świętokradzki gwałt mocarzy,

Gdy na trzy kraje kraj nasz rozcięto,

Pozostał duch wolnych mularzy.

Budowco! Zawieś na brata szyję

Tajemmic naszych znamiona,

Niech on, niech naród, niech Loża żyje,

Pod znakiem Napoleona!

Szedł Polak torem licznych wspólbraci

Za Franków Orła przewodem,

Zdobył krwią cząstkę dawnej postaci

I stal się w Tylży Narodem.

W 1812 roku Wielkim Mistrzem zostaje Stanisław Kostka Potocki, zachowując tę godność do roku 1820. To okres rozkwitu wolnomularstwa, a więc i jego poezji. Mimo klęski Napoleona, loże, korzystając z liberalnego nastawienia Aleksandra, nader szybko dostosowują się do sytuacji: zamiast Napoleona nazywają Aleksandra swym ojcem i protektorem, wznawiając prace jeszcze przed rozpoczęciem Kongresu Wiedeńskiego.

Znamienny w treści jest pierwszy skromny zbiorek Tadeusza Wolańskiego ${ }^{8}$ z 1817 rokı zawierający w pięknej oprawie pięć pieśni

na obchód uroczystości Narodzin Najjaśniejszcgo Cesarza i Króla Aleksandra wygotowane na użytek lóż w Królestwie Polskim przez Tadeusza Wolańskiego mistrza katedry i założyciela spr[awiedliwej] i dosk[onałej] 
loży pod nazwiskiem Doskonałego Zjednoczenia na Wschodzie Włoclawka pracującej.

Jeden z utworów to przeróbka utworu wykonanego w Świątyni Mądrości w grudniu 1806 roku":

1806

Zlóżmy mu wdzięczności pienia, Niech żyje Polski obrona,

Niech czczą późne pokolenia WIELKIEGO NAPOLEONA!

Juz w brzegach Wisły i Warty

Miecz błysnął jego zwycięski, Zjednoczy nasze umysły,

Pamiętny na dawne klęski.

Dopiero w opublikowanym rok później obszernym zbiorze 100 utworów autor przeróbki podpisał się pod nową wersją: „Tadeusz Wolański (w części)”. Nowy zbiór zawieral także przerobioną pieśń Odchodzacym u'ojounikom z 1807 roku, a także, obok siebie dwa bardzo podobne utwory poświęcone Wodzou' u'ojsk polskich Br|atu] Jázefon'i Poniatou'skicmu i Wodzouri wojsk polskich W[ielkiemu] Ks[ięciu] Konstantemu, obie z podaniem autora: „Br[at] Tadeusz Wolański”"!":
Mularze! zaśpicwajmy
Zacnemu Józefowi.
Mularze! zaśpiewajmy
Zacnemu Konstantemu. Niech zabrzmi głos wiwatów, Niech czczą późne pokolenia Króla walecznych Sarmatów!

[strofa opuszczona]

Tak zgasła masońska poezja napoleońska w Polsce i kult Napoleona w lożach. Bracia nie cieszyli się długo przychylnością nowego „Króla Sarmatów”. Ukazem carskim loże wolnomularskie zaprzestały działalności w 1821 roku. A tradycja napolcońska zachowała się w rodzinnych pamiątkach i legendach oraz rosnącej fali świetnej literatury i sztuki.

\footnotetext{
"Ibidem, s. 122 i karta 26.

10) Ibide'm, s. 133 i karty 89, 90.
} 
Aneks: Wybór fragmentów pracy magisterskiej

\author{
Krzysztof Marek Ostrowski \\ Wydział Filologiczny Uniwersytetu Warszawskiego \\ filologia polska \\ POLSKA POEZJA MASOŃSKA \\ praca magisterska \\ pod kierunkiem \\ prof. dr Zdzisława Libery \\ 1962
}

SPIS TREŚCI [wyróżnione zostały fragmenty przytoczone poniżej]

Wstęp: Przedmiot, zakres, cel, źródla i układ pracy [s. 4]

CZEŚŚC I

Rozdział 1: Charakter związków masońskich [s. 9]

Rozdział 2: Charakter poezji masońskiej [s. 26]

Rozdzial 3: Poezja masońska w Europie [s. 39]

CZĘŚĆ II

Rozdział 4: Początki i rozwój wolnomularstwa polskiego 1738-1810. Pierwsze utwory poetyckie [s. 53] — Wolnomularstwo polskie w XVIII wieku; Loże w zaborze pruskim i pierwszych latach Księstwa Warszawskiego; Pieśni wolnomularskie wyd. Elsnera Rozdział 5: Rozkwit wolnomularstwa polskiego i jego poezji [s. 75] — Wielki Wschód 1810-1821; Twórczość masońska K. Brodzińskiego; Twórczość poetycka lóż warszawskich; Twórczość krakowskiej loży Przesąd Zwyciężony; Twórczość poetycka lóż wileńskich; Twórczość poetycka lóż lubelskich; Pieśni uolnomularskie Feliksa Gawdzickiego Rozdzial 6: Pieśni u'olnomularskie z Łomży [s. 103] — Łomża w początkach XIX wieku; Wolnomularstwo płockie i loża Wschodzącego Słońca; Pieśni z loży Wschodzącego Słońca; Przedruki ze zbiorku warszawskiego; Pozostałe utwory

Rozdział 7: Działalność poetycka i wydawnicza Tadeusza Wolańskiego [s. 117] — Sylwetka T. Wolańskiego; Pieśni wolnomularskie na obchód uroczystości narodzin; Pieśnik wolnomularski (Układ; Utwory Wolańskiego; Utwory ze zbiorku warszawskiego; Utwory ze zbiorku lomżańskiego; Pozostałe utwory)

Zakończenie: Znaczenie poezji masońskiej w literaturze polskiej [s. 141]

Wykaz drukowanych zbiorów polskiej poezji masońskiej [s. 147]

Wybór opracowań dotyczących wolnomularstwa [s. 149]

CZĘŚĆ III: Bibliografia polskiej poezji masońskiej

Objaśnienia [s. 152] — Indeks autorów [s. 153] — Indeks zbiorków [s. 155] - 220 kart

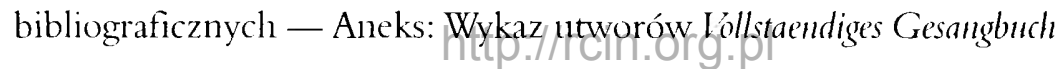




\section{Rozdział 2 \\ Charakter poezji masońskiej}

Zjawisko poezji masońskiej wywodzi się z obyczaju wspólnych śpiewów wprowadzonego przez rytualy masońskie. Rytuały nie czynią z obyczaju tego obrzędowej ceremonii, ale zalecają towarzyszenie muzyki i śpiewu w różnych momentach prac lożowych. Bardzo znaczna ilość utworów przeznaczonych do śpiewania w loży stołowej każe zwrócić uwagę przede wszystkim na jej rytuał. Jak wspomniałem, lożą stołową nazywano rytualny bankiet odbywany zazwyczaj po zwykłym zebraniu loży. Nad organizacją i przebiegiem bankietu czuwali specjalni urzędnicy: Mistrz Obrzędów i Stuardzi, a obsługiwali afiliowani do związku na specjalnych prawach Bracia Stużący. Stoły ustawiano w podkowę otwartą w kierunku zachodu. Mistrz Katedry zasiadał pośrodku, Urzędnicy i Goście od wschodu, a pozostali bracia od południa i północy. W czasie bankietu spełniano przewidziany ceremoniał i porządek toastów, a jednocześnie:

przez cały czas uczty lub znaczną jej część Bracia wysługujący się Towarzystwu przez swój talent muzyki, a stąd wolni od opłat miesięcznych, przygrywali Braciom pracującym i strzelającym..."

Oto porządek loży stolowej wedhug jednego z zachowanych rytuałów ${ }^{12}$ : po otwarciu loży spełniano zdrowie króla oraz rozlegała się „muzyka instrumentalna”. Następnie wznoszono toast na cześć Wielkiego Wschodu i odśpiewywano hymn do wolności (rytuał ten jest tak szczegółowy, iż podaje nawet numer pieśni, prawdopodobnie z jakiegoś większego zbioru).

Następnym z kolei zdrowiem należało uczcić Mistrza Katedry, po czym odśpiewywano mu pieśń. Po zdrowiu Mistrzów i Urzędników - muzyka, a następnie zdrowie wszystkich lóż i śpiew o przyjaźni. Po spełnieniu zdrowia Uczniów i podziękowaniu Brata Ucznia wypijano zdrowie Zakonu w specjalncj ceremonii łańcucha, a następnie dziękowano braciom „ozdobionym talentami” oraz gościom, i przeprowadzano składkę na Braci Służących i składkę na ubogich, a tej ostatniej towarzyszyła pieśń, i wreszcie „zamknięciem zwyczajnym” kończono lożę. Nie tylko przytoczony rytuał, lecz i większość innych wspomina o obrzędzic pieśni łańcuchowych:

"Frankmasonia mężzyzn i kobiet symboliczma czyli niskich stopnióu, z dzicha "XII tomad folio Ceremonies et

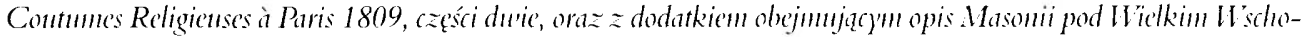
dem Francuskim zan'anty 'u' sekretny'm seksterniku stusacy'm dla braci, druk b. m. r., 152 s., egz. Biblioteki Uniwersyteckiej w Warszawie (dalej: BUW) sygn. 91144, s. 68.

12 Archiwum Główne Akt Dawnych w Warszawie (dakej: AGAD), Mas. II 1/1. 
Bracia, powstawszy, skrzyżowawszy na piersiach ręce i dloniami każdy trzymając z bliskimi dwoma, zrobią lańcuch, w którym będąc, śpiewaja na chory $z$ deski wierszami zrobionej na zaletę ligi Masonów ${ }^{13}$.

Obrzęd pieśni lańcuchowych miał symboliczne znaczenie: „łańcuch” i wspólna pieśń mają świadczyć o jedności, sile wszystkich wolnomularzy zlączonych węzłami przyjaźni i wspólnych idei - znaczenie to uwypuklone jest w mickiewiczowskim: „Wspólnymi łańcuchy opaszmy ziemskie kolisko”.

W omówionym wyżej rytuale pieśí łańcuchowa towarzyszyła spełnieniu zdrowia związku, i następować maila po mowie Dozorcy. Inne toasty spełniano również w specjalnym obrządku. Oto przykład pierwszego, otwierającego bankiet toastu:

Dobądźcie orężów. Damy ognia za zdrowie Napoleona Wielkiego Cesarza Francuzów, Króla Włoskiego, protektora Ligi Reńskiej. Czują serca nasze, co mu winna ludzkość, co ziemia polska, co zakon wolnomularza. Złóżmy hołd podziwienia największemu z ludzi i połączmy życzenia, żeby Wielki Świata Budownik błogosławił zawsze związkowi oręża jego. Uczcijmy to zdrowie ogniem najsilniejszym. Ręka za broń — broń do góry — do ust — ognia — większego ognia — ognia najdzielniejszego $-\mathrm{raz}-\mathrm{dwa}-\operatorname{trzy}^{1+}$.

Nie na osobę Napoleona, lecz na formę toastu chciałbym zwrócić uwagę: rytuały loży stołowej podają specjalny słownik obowiązujący w czasie bankietu, i w tym słowniku nie tylko spełniane są toasty, lecz i śpiewane pieśni. Broń - to szklanki, strzelanie — picie, wino czerwone i biale: proch pospolity i tęgi, noże - miecze, serweta - choragiew, a muzyka i śpiew - rysunek.

Nieco inny obrządek i słownik obowiązywał w loży stołowej adopcyjnej odbywanej przez lożę męską i afiliowaną przy niej lożę kobiecą. O lożach kobiecych trzeba wspomnieć również ze względu na znaczną ilość pieśni Siostrom-masonkom poświęconych. Nie wprowadzając szczegółowych warunków istnienia i pracy tych lóź, chıcę tylko zaznaczyć, iż rządziły się one własnym rytuałem, nieodsłaniającym jednak żadnych tajemnic związku. Poza samodzielnie odbywanymi pracami siostry uczestniczyły w niektórych obrządkach lóż męskich, a przede wszystkim we wspólnych bankietach. Rytuał nakazywał braciom cześć i hołdy siostrom, co przeważnie sprowadzalo się do odśpiewania na cześć masonek specjalnej pieśni. Wspólne prace były przedmiotem licznycl skandali i szeregu zarzutów o niemoralności masonerii. 
Pieśni towarzyszyły lożom nie tylko w czasie bankietów. Obrzęd pieśni łańcuchowych był zazwyczaj obrzędem zamykającym każdą lożę. Po każdym zebraniu odbywała się też składka na ubogich, a towarzyszyły jej pieśni jałmużnicze. W czasie „podróży” odbywanych przy przechodzeniu na wyższy stopień „Bracia muzycy zaczynają pienie na głosy i instrumenty", wreszcie muzyka i śpiew uświetnia ważniejsze uroczystości lożowe.

Omawiając ten rodzaj śpiewów, przechodzimy do zwrócenia uwagi na inny aspekt masońskiej poezji: na jej okazjonalność. Poprzednio wyróżnione pieśni stołowe, łańcuchowe, jałmużnicze czy towarzyszące podróżom określone były w swym charakterze przez rytuał masoński i przewidziane przez ten rytuał ceremonie. Pieśni tworzone na uroczystości lożowe dotyczyły przeważnie ściśle określonej okazji: wyboru na Mistrza Katedry brata $x$, obchodu imienin Mistrza w roku y, rocznicy założenia loży, imienin króla itp. Z czasem wśród pieśni tych pojawily się i bardziej ogólne, nieprecyzujące szczegółów uroczystości, roku, imienia itp., a więc przeznaczone dla lóż niezdolnych do podjęcia wlasnej twórczości - ale charakter tych utworów nie uległ zmianie: pozostały one w większości utworami panegirycznymi, przesadnie wychwalającymi uroczystość, jaką miały uświetniać. Uroczystości lożowe przeprowadzane były wedlug specjalnie ustalonego programu, w którym muzyka i poezja odgrywały znaczna rolę. Oto sprawozdanie z obchodu imienin Ludwika Osińskiego, Mistrza Katedry loży Świątynia Izis w 1812 roku $^{15}$. Lożę otworzył I Dozorca, który po zagajeniu prac oznajmil cel posiedzenia oraz doniósł, iż solenizant czeka w przedsionku loży. Następnie wyznaczył deputację do wprowadzenia Mistrza Katedry do loży. W jej towarzystwic Mistrz wszedł do świątyni przy akompaniamencie muzyki i przeszedl pod „sklepieniem stalowym" utworzonym ze szpad braci. Dozorca poprosił o pozostawienie w jego ręku młotka i zgodę na pokierowanie pracami. Gdy Mistrz na to przyzwolil, został zaproszony na tron stojący po prawej stronic Przewielebnego trzymającego młotek. W krótkiej przemowie trzymający młotek I Dozorca wezwał Brata Mówcę do wygłoszenia okolicznościowego przemówienia, a

loża cała, pałająca chęcią udowodnić swemu Mistrzowi Katedry, iż wystawione przez Najdoskonalszego Brata Mówcę uczucia są jej własnymi i z serca pochodzącymi, do oklasków przez Przewielebnego Mlotek Trzymającego wezwana, to z uniesienia po kilkakroć powtórzyła, a życzenia swoje wykrzyknieniem wynurzyła.

Następnie dal się słyszeć hymn

egzekwowany przez Braci Amatorów, a rozdrukowany, Braciom wszystkim przytomnym, aby wyrazy jego dzielili, rozdanym został. 
Po hymnie jeden z czeladników odczytał „wiersz stosowny do okoliczności przez siebie zrobiony”. Mistrz Katedry na życzenia „odpowiedzieć raczyl”. Następnie przyjęto członków honorowych loży i podziękowano wszystkim za obecność. Lożę zakończyło zbieranie jałmużny i muzyka.

Na podstawie opisu tej pompatycznej uroczystości można sobie wyrobić pogląd o utworach poetyckich w loży tej recytowanych; na pewno nie odbiegały one nastrojem od „uniesień” i „wynurzeń”. Pieśni i deklamacje towarzyszyły nie tylko uroczystościom, których nastrój pozwalał na „uniesienia”.

Z zachowaniem wzniosłego nastroju, ale jednocześnie powagi i smutku, wykonywane były pieśni ku czci zmarłych braci w odprawianej dla uczczenia ich pamięci loży żałobnej.

Program loży żałobnej po śmierci księcia Józefa Poniatowskiego ${ }^{16}$ przewidywał, iż „muzyka odezwie się z przyległego pokoju”, a w loży będzie deklamowana „poezja liryczna”. Po pierwszej części deklamacji miało nastąpić zasłonięcie popiersia zmarłego, po drugiej „daleka i do końca towarzysząca muzyka”.

Dalej następowało odsłonięcie obrazu, pełnienie straży honorowej i dokończenie deklamacji, po czym „odezwie się śpiewanie dalekie z przedłużoną nieco muzyką”. Wreszcie „nastąpią trzy strofy śpiewane w loży, podczas trzeciej Bracia stawiają w łańcuchu braterskim i w końcu strofy czynią znak". Zarówno w Księdze Budou'niczej $j^{17}$, jak i w papierach Wielkiego Mistrza Kostki Potockiego ${ }^{18}$ znaleźć można wiele wzmianek o śpiewach podczas uroczystości Wielkiego Wschodu; podczas obrzędu instalacji Wielkiego Mistrza, uroczystości Św. Jana i ogloszenia Wielkiego Wschodu, imienin Wielkiego Mistrza itp.

Rytualny i okazjonalny claarakter poezji masońskiej zaciążył poważnie na treści utworów; bądź obracają się one wokół podstawowych haseł ideologii masońskiej, bądź omawiają okazje, jakie mają uświetniać. Również forma utworów podporządkowana jest rygorom; jako przeznaczone do śpiewu lub deklamacji, utwory te przybierają formy drobnych gatunków poetyckich: pieśni, ód, trenów żałobnych, lub co najwyżej czasami rozwinięte są w ramy kantat ze skomplikowanym podziałem na chóry i głosy.

Rytualny i okazjonalny charakter utworów poezji masońskiej czyni szczególnie interesıjącymi okoliczności ich powstawania i rozpowszechniania, gdyż oba te zjawiska zależą od warunków stworzonych w ramach związku i od jego działania jako organizacji. Ze względu na swój charakter poezja masońska jest przecież produkcją powstałą na zamówienie związku i rozpowszechniana na jego użytek. Stwierdzenie to przynosi

\footnotetext{
"AGAD Mas. II 2/54.

ir AGAD Kanc. Nowos. 831.

is AGAD ApP 311.
} 
wiele konsekwencji mających poważne znaczenie dla istoty i walorów poezji masońskiej. Jej powstanie i rozwój zależne są przede wszystkim od stanowiska i sytuacji organizacyjnej lóż. Historia polskiej poezji masońskiej dostarcza wymownych przykładów, iz produkcja poetycka powstaje dopiero w okrzepłych i dobrze zorganizowanych lozach, kiedy to nie zewnętrzne trudności, ale rytualne prace zaprzątają przede wszystkim lożowych braci.

Pierwszym problemem organizacyjnym jest skupienie w lożach ludzi zdolnych podjąć twórczość artystyczną. Bracia-śledziciele, wyznaczeni do sprawdzenia zalet profana ubiegającego się o przyjęcie do loży, mieli między innymi za zadanie stwierdzić, czy kandydat jest „gotów służyć Braci muzyką, pisaniem, pędzlem lub sprawowaniem interesów"1925. Z przytaczanych cytatów wiemy juz, iz bracia „obdarzeni talentami” cieszyli się w lożach specjalnymi względami: mogli być wolni od opłat miesięcznych, otrzymywali specjalne podziękowania itp. Loże wykształciły też specjalny urząd do organizowania i kierowania produkcjami wokalno-muzycznymi: Dyrektora lub Brata I Iarmonii. Urząd ten istnial w Polsce między innymi przy Wielkim Wschodzie, lożach litewskich, warszawskich i płockich. Możliwość tworzenia w ramach lóż masońskich dawała szansę prezentowania utworów nie tylko sławnym w świecie literackim braciom, lecz i wszystkim tym, którzy twórczość poetycką uprawiali amatorsko. Dzięki temu motywacja podejmowania produkcji poezji masońskiej jest bardzo różna: dla sławnych ówcześnie Osińskiego czy Koźmiana utwory masońskie były kaprysem i marginesem ich twórczości literackiej, dla młodego Brodzińskiego — szkołą i początkiem karicry, a dla nauczyciela matematyki z Lublina - prawdopodobnie jedyną szansą zapoznania szerokiego grona z amatorskimi próbami. Grono twórców masońskiej poezji jest więc w swym skladzie niespójne, a poziom utworów bardzo kontrastowy.

Grono odbiorców ograniczone bylo wyłącznie do czlonków lóż, gdyż otaczanie tajemnicą prac masońskich dotyczylo także wszelkiej produkcji piśmienniczej związku.

Skupienie odbiorców poezji w niezależnych jednostkach organizacyjnych, jakimi były loże, uzależniało rozpowszechnianie utworów od rozwoju kontaktów miedzy poszczególnymi lożami. Kontaktom tym sprzyjało przede wszystkim istnienie centralnej władzy Wielkiego Wschodu. Podległe loże poprzez swych reprezentantów, jak i w bezpośredniej korespondencji, przekazywały Wielkiemu Wschodowi informacje o swych pracach i otrzymywaly wiadomości o działalności innych lóż. Istniala również wymiana korespondencji miedzy poszczególnyni lożami: wymieniano obrazy lóż (spisy członków), życzenia itp. Z tych wzajemnych kontaktów powstała jedna z form rozpowszechniania utworów poetyckich: ich bezpośrednia wymiana. Znamy na przykład list loży płockiej Albertyna Doskonałości do warszawskiej Świątyni Mądrości, w którym czytamy między imnymi:

19) Frankmasonia..., op. cit., s. 24-25. 
braterskiego nadesłania nam pieśni z melodyjami na ręce naszego Najprzewielebniejszego Mistrza lub Brata Drugiego Dozorcy oczekiwać chcemy ${ }^{211}$.

Pieśni nadsyłano również Wielkiemu Wschodowi: w 1785 roku w jego sprawozdaniu czytamy, iż loża Jutrzenka Bizantyjska ze Wschodu Konstantynopola (pracowała wśród polskiej emigracji) nadesłała listę członków wraz z szeregiem mów i wierszy²1.

W papierach Wielkiego Mistrza Stanisława Kostki Potockiego znajdujemy listy loży Jutrzenka Wschodząca z Radomia i Świątynia Równości z Lublina, donoszące o obchodzie imienin Wielkiego Mistrza i załączające pieśni z tej okazji śpiewane ${ }^{22}$.

Zasadniczą jednak role w kolportażu masońskiej poezji odegrało przyjęcie przez loże drukowanej formy rozpowszeclniania materiałów związkowych. Wprowadzenie druku wiązało się nie tylko $z$ koniecznością posiadania przez loże odpowiednich środków technicznych i finansowych, lecz przede wszystkim z obawą dostania się druków w ręce profanów, co w znacznie mniejszym stopniu grozilo pojedynczym egzemplarzom rękopiśmienniczym przechowywanym w archiwach lóż. Wspomniane jednak potrzeby coraz ściślejszych kontaktów między lożami, a także chęć nadania masońskim materiałom trwalszej i dostępniejszej formy, przelamały te obawy, i jako druki poczęly ukazywać się sprawozdania Wielkiego Wschodu, obrazy lóż, formularze zaświadczeń i zawiadomień, a także mowy i utwory poetyckie.

W 1818 roku polski Wielki Wschód stosunkiem głosów 18 do 8 przyjął uchwałę popierającą drukowanie obrazów, śpiewów i mów, „ile by te tajemnic Wolno-Mularskich nie odsłaniały" ${ }^{23}$. Uchwała przyjęta została dopiero po dłuższej dyskusji, a stosunek głosów wskazuje, iż te obawy związane z publikowaniem masońskich materiałów były nawet w najwyższych władzach trudne do przezwyciężenia.

W zakresie utworów poetyckich możliwości druku wywolywały dwie tendencje. Pierwsza przejawiała się w ulotnych drukach utworów okazjonalnych: druk wiersza czy mowy stanowił jeszcze jedno uświetnienie jakiejś lożowej uroczystości (przypomnijmy sobie opis imienin Osińskiego). Drugą tendencją było gromadzenie utworów poetyckich w większe zbiorki mające ulatwić wymagane przez rytuał i zwyczaj wprowadzanie pieśni masońskich. Zbiorki te znamy i w formie rękopiśmienniczej²4, ale jako druki uzyskiwały one możliwości jednoczesnego dotarcia i wykorzystywania w wielu lożach, i dlatego często opracowywane były dla znacznej liczby lóż pracują-

In Według: S. Malachowski-Łempicki, Uohnomularstu'o polskie a muzjka, "Wiadomości Muzyczne” 1925 nr 7,1926 nr 11-12.

2 AGAD Mas. II 2/28.

$\therefore$ ACiAD Mas. II 2/28.

2.3 Kiegea Budou'nicza Wielkiego Wschodu, AGAD Kanc. Nowos. 831.

It ACAAD Mas. VIII 9/4, VIII 9/1 thttp://rcin. org. p 
cych pod wielką lożą krajową czy Wielkim Wschodem. Drukowane zbiorki stanowią najwyższą formę rozpowszechniania druków masońskich, i dlatego szczególnic na gruncie polskim ukazanie się każdego zbiorku jest wydarzeniem w historii masoniskiej poezji.

Interesujące wnioski wynikają z porównywania druków masoniskich. Większość z nich ozdobiona była różnorodnymi winietkami z emblematami wolnomularskimi. Otóż tę samą winietkę spotykamy w druku kantaty Brodzińskiego, w druku niemieckiego wiersza jednej z warszawskich lóż, a także w dziełku niemieckiego mularza wydanym w kilka lat później w Lipsku! ${ }^{55}$ Nie jest to przypadek lub zbieźność rysunku; przykładów takich mógłbym przytoczyć więcej, dowodzą one, iż prawdopodobnie polskie drukarnie korzystały z niemieckich sztanc lub niemieckiego papieru z nadrukowanymi winietkami.

Stosunkowo mało znanym przejawem masońskiej dzialalności kulturalnej były dość liczne i dobrze zaopatrzone biblioteki lożowe. Biblioteki te nie tylko zapewniały usystematyzowane przechowywanie masońskiej poezji, lecz takze gromadziły interesujące dzieła z wielu dziedzin i nie tylko masońskiego pochodzenia. O bibliotekach istniejących w Polsce mamy dosyć dokładne zbiorcze informacje dzięki skrupulatności komisji, która na zlecenie Nowosilcowa zajmowała się rekwirowanie zbiorów masońskich ló $\dot{z}^{26}$.

Ogółem zgromadzono 4998 książek z bibliotek lóż Królestwa Polskiego, trzeba jednak pamiętać, iż część materiałów została przed władzami rosyjskimi ukryta. Ze szczególowego sprawozdania dotyczącego 2264 książek dowiadıjemy się, iż w bibliotekach lożowych znajdowały się np. prace z astronomii, ekonomii politycznej, metalurgii, podręczniki do nauki języków itd. Sprawozdanie to notuje również $81 \mathrm{dziel}$ poetyckich w 96 tomach. Biblioteka Wielkiego Wschodu liczyla 770 pozycji. W Archiwum znajdowal się między innymi zbiorek pieśni z loży z Nieświeża, a także teczka z napisem Poezje, zawierająca „śpiewy, kantaty i marsze”. Archiwum loży Świątynia Stałości w Warszawie zawierało 45 utworów poetyckich.

Opisane wyżej cechy: zorganizowana twórczość dla zamkniętego kręgu odbiorców i jej instytucjonalne wykorzystanie i rozpowszechnianie stanowią o interesującej odrębności problemów poezji masońskiej. Do odrębności tych zaliczyć tez można zagadnienie języka twórczości wolnomularskiej.

Mimo iż kolebką masonerii była Anglia, na kontynencie europejskim loże powstawały głównie za pośrednictwem Francji, która najwcześniej przyswoila sobie angielskie statuty i rytuały. Dzięki temu język francuski był początkowo językiem wszechwładnie panującym w lożach niemieckich i polskich. 
Opierając się na francuskich statutach prowadzono po francusku prace, śpiewano francuskie pieśni, a w Niemczech wydawano nawet ich zbiorki. Powstanie w Polsce centralnej narodowej władzy Wschodu Polskiego w 1784 roku nie oznaczało bynajmniej powszechnego przyjęcia języka polskiego. Wprawdzie niektóre loże pracowały już po polsku, ale część przystępujących do Wielkiego Wschodu lóż prowadziła prace po francusku i niemiecku. Język niemiecki trafił do działających na terenie Polski lóż dzięki tradycyjnym, trwającym przez cały okres saski związkom lóź pracujących w Polsce z lożami działającymi w Niemczech. W chwilą olbrzymiego wzrostu siły i znaczenia lóż niemieckich większość z nich zaczęła używać języka niemieckiego, a zasięg jego wpływu objął i niektóre loże na ziemiach polskich. Sytuacja taka utrzymała się do końca istnienia w Polsce wolnomularstwa: pod Wielkim Wschodem Polskim pracowały loże w języku francuskim i niemieckim, a Wielki Wschód zapewnial im pełne prawa, utrzymując w gronie swych urzędników zarówno Mówców, jak i Sekretarzy do obu tych języków. Sprawozdania Wielkiego Wschodu dopiero od roku 1787 prowadzone są po polsku. Najwyższa Kapitula przyjęla język ojczysty w 1812 roku, a rozwój polskiej poezji masońskiej datuje się dopiero od czasów Księstwa Warszawskiego. Język prac loży nie oznaczał, iż członkami jej są Francuzi czy Niemcy; w lożach tych przeważnie pracowali w większości Polacy. Loże te rozwijaly wlasną twórczość poetycką oczywiście po francusku czy niemiecku, a przede wszystkim asymilowaly powstałe we Francji czy Niemczech pieśni. Zupełnie odrębną grupę stanowiły loże zależne od władz obcych, a pracujące na ziemiach polskich. Byly to przeważnie loże niemieckie zależne od wielkich lóż berlińskich, a pracujące w okresie nieistnienia wolnomularstwa polskiego w latach 1794-1810. W działalności tych lóż Polacy brali czynny udzial, a nawet uzyskiwali pozwolenie prowadzenia prac w języku polskim, i w tych właśnie lożach powstały pierwsze polskie utwory poetyckie. W ten sposób wytworzona została skomplikowana sytuacja, w której w lożach — w sensie wladzy - polskich kultywowana jest poezja francuska i niemiecka, a w lożach niemieckich powstaje twórczość polska. Sytuacja ta jest trudna do omówienia i oceny, wydaje się jednak, iż w działalności lóż obcojęzycznych nie można doszukać się przeszkód dla rozwoju polskiej poezji masońskiej. Przeszkody te zniknęly z chwilą powstania centralnej narodowej władzy Wielkiego Wschodu, gdyż fakt ten wytworzył świadomość narodową wśród Polaków-masonów, bez względu na lożę, w jakiej pracowali.

Działalność natomiast lóż obcojęzycznych była swojego rodzaju misją ułatwiającą asymilowanie w Polsce obcych wplywów kulturalnych, co miało szczególne znaczenie w odniesieniu do lóż niemieckich. Loże te odegrały bowiem znaczna rolę w przenikaniu do Polski poezji niemieckiej nie tylko w formie interesujących pieśni masońskich, lecz również poprzez najwybitniejsze współczesne dzieła literatury niemieckiej udostępnione polskim Braciom. Wedlug informacji niemieckich opracowań ${ }^{27}$ przy jednej 
z warszawskich zależnych od Berlina lóż (zum Goldencn Leuditer) założono w latach 1787-1805 kółko czytelnicze i bibliotekę, dostępne nie tylko członkom loży (wśród których spotykamy kilka wybitnych w kulturze polskiej nazwisk), lecz również ich rodzinom i przyjaciołom. Biblioteka ta oprócz dzieł masońskich, a także I Iomera, Wergiliusza, Liwiusza, Tacyta, zawierała przede wszystkim dzieła współczesnej literatury niemieckiej, między innymi Claudiusa Wandsbeker Boten, powieści Jean Paula, Briefen zur Befördernung der Humanität Herdera, tłumaczenia Szekspira, ballady i dramaty Schillera, Hermana i Dorote Goethego.

Przytoczone przykłady nie są bez znaczenia dla studiów nad poezją masońską w Polsce. Interesując się przede wszystkim utworami w języku polskim, nie należy zapominać o ich powiązaniach z pieśniami francuskimi i niemieckimi, zarówno asymilowanymi z Francji i Niemiec, jak powstałymi w działających na ziemiach polskich lożach. Wpływy lóż niemieckich wymagałyby specjalnego i szerszego opracowania.

Omawiając charakter poezji masońskiej, chiciałem przede wszystkim zwrócić uwagę, iz zarówno w przeznaczeniu, jak i systemie powstawania i rozpowszechniania różni się ona od ogólnie obowiązujących norm twórczości poetyckiej. Różnice te czynią sam fakt istnienia tego typu poezji bardzicj interesującym niz walory artystyczne poszczególnych utworów.

\section{Rozdzial 4 \\ Początki i rozwój wolnomularstwa polskiego 1738-1810. Pierwsze utwory poetyckie}

\section{Loże w zaborze pruskim i pierwszych latach Księstwa Warszawskiego}

Omawiając działalność wolnomularstwa w Polsce porozbiorowej, powrócić musimy do poruszanego już problemu lóż zakładanych na ziemiach polskich przez lożc zagraniczne. Po III rozbiorze sytuacja polityczna uniemożliwiła działanie polskich lóż, a w dwóch zaborach przerwała w ogóle prace wolnomularskie. W zaborze rosyjskim, jak i w całej Rosji, od 1797 roku związki masońskie były surowo zakazane, w zaborze austriackim podobny zakaz obowiązywał od roku 1795, w zaborze pruskim natomiast działały tylko loże zależne od trzech wielkich lóż berliniskich, pracujące po niemiecku.

Wolnomularstwo niemieckie przeżywało wówczas okres wspaniałego rozkwitu.

Mularze Fryderyk Wielki i Fryderyk Wilhelm II otaczali loże szczególną opieką, a Fryderyk Wilhelm III. wydając zakaz działalności wszelkich towarzystw, nie objął nim trzech wielkich lóż berlińskich, uprawniając je do zakładania zależnych od siebie lóż i nie ograniczając w ten sposób działalności wolnomularstwa, a tylko centralizując jego władze. Owe trzy niezależnie od siebie pracujące loże: Grosse Landesloge, Grosse Mutterloge zu den Drei Weltkugelu i loża Ropal York zur Freundschaft już przed rozbiora- 
mi zakładały loże na ziemiach polskich, między innymi w Gdańsku, lecz w okresie porozbiorowym działalność ich szczególnie wzrosła. Grosse Landesloge erygowała loże w Warszawie, Toruniu, Rawiczu i Białymstoku. Loża Zu den Drei Weltkugeln - w Płocku, Kaliszu, Kwidzynie, Malborku i Gdańsku. Loża Royal York - w Płocku, Kaliszu, Grudziądzu i Gdańsku.

Wspomniałem już rolę lóż warszawskich w propagowaniu niemieckiej literatury; w tym miejscu chciałbym podać kilka informacji o działalności tych lóz. Powstała w roku 1797 loża Zum Goldenen Leuchter rozwijała się niezwykle szybko. Liczba 14 członków w 1797 roku wzrasta do 50) w roku 1799 i 72 w roku 1801. W 1802 roku powstaje druga loża: Friedrich Wilhelm zur Saule. Jej mistrzem jest Polak Jan Brodowski. W roku 1805 loża Zum Goldenen Leuchter liczyła 75 członków w Warszawie i 40 na prowincji. Mistrzem loży był generał Chlebowski, a członkami między innymi gen. Niemojewski, gen. Piotr Reych, Józef Elsner, Ludwik Dmuszewski, Józef Orsetti.

Warto przypomnieć, iż loża ta opisana jest bardzo wiernie w Popiotach. Przytoczone przez Żeromskiego pieśni są fragmentami utworów zawartych w zbiorku Elsnera. 21 stycznia 1805 roku loża ta, za zgodą Grosse Landesloge, rozpoczyna prace po polsku, rozdzielając się na dwie loże: niemiecką i polską. Uroczystość ta uświetniona była odśpiewaniem hymnu Dmuszewskiego z muzyką Elsnera:
O święto! Dniu uroczysty,
Dniu od dawna pożądany,
W nim łączy węzeł wieczysty
I Sarmaty, i Germany.

Utwór ten wydany był drukiem pt. Hymn w' doskonatej loży' Śu'. Jana Ztotego Lichtarza na pieruszy'm zgromadzenin w' jez)ku polskim śpieu'any 21 stycznia 1805.

W loży Zum Goldenen Leuchter powstało już wcześniej kilka utworów poetyckich, między innymi wiersz gen. Chlebowskiego ${ }^{28}$, ale komponowane one były po niemiecku; utwór Dmuszewskiego rozpoczyna serię utworów polskich powstałych w latach 1805-1810, a zebranych i wydanych przez Józefa Elsnera. Opisując je dokładniej z okazji omawiania zbiorku Elsnera, chciałbym w tym miejscu uszeregować fakty wydanie tego zbiorku poprzedzające.

W maju 1805 roku rozpoczyna prace loża Świątynia Mądrości, założona również przez Grosse Landesloge. Do loży wstąpili Polacy ze Złotego Lichtarza, prace odbywano po polsku, a wedlug Friedrichsa ${ }^{20}$ nawet korespondencję z lożą-matką prowadzono po polsku z niemieckim tłumaczeniem. Warunkiem stawianym przez lożę-matkę był

\footnotetext{
Is Utwory te wspommiane są w opisie archiwum loży Przedsionek Stałości. AGAD Kanc. Nows. 595.

29) Patrz przypis 33 .
} 
jedynie warunek wyboru Mistrza Katedry znającego język niemiecki. Loża liczyła początkowo 47 członków, Mistrzem był Piotr Reych, a członkami między innymi Osiński, Dmuszewski, Adamczewski, Bogusławski.

W roku 1806 loża płocka Albertina zur Vollkommenheit założona w roku 1803 przez lożę berlińską Zu den drei Weltkugeln na skutek prośby braci Polaków nieznających języka niemieckiego otrzymała prawo prac w języku polskim, i niezwłocznic nawiązała kontakt ze Świątynią Mądrości, prosząc ją między innymi o nadeslanie pieśni z nutami.

Natychmiast po utworzeniu Księstwa Warszawskiego powstała w 1807 roku zależna od Wielkiego Wschodu Francuskiego, a zlożona przeważnie z wojskowych, loża Bracia Polacy Zjednoczeni pod młotkiem gen. Axamitowskiego. Członkami byli między innymi gen. Różniecki, gen. Kamieniecki, Sapiehowie. Członkiem honorowym był ksiązę Józef Poniatowski. Loża otaczała wielką czcią Napoleona, protektora masonerii francuskiej.

Powstanie Księstwa Warszawskiego sprzyjało odrywaniu się lóż od Berlina i umożliwialo restaurowanie polskiego wolnomularstwa. W roku 1809 wznowila pracę loża Gottin von Elensis (założona w roku 178()) oraz Świątynia Izis (założona również w roku 178()). Do tej ostatniej przeszli członkowie Świątyni Mądrości. 26 lutego 1810 roku otworzono wielką lożç kapitularną Gwiazda Wschodnia, powstałą z dawnej loży Stanislaw August pod Gwiazdą Pólnocną. 22 marca ogłoszono powstanie Wielkiego Wschodu Narodowego. Do Wielkiego Wschodu poza czterema wymienionymi wyżej lożami przystąpiły jeszcze reaktywowane w 1810 roku loże Przesąd Zwyciężony z Krakowa (założona w 1786 roku) i Bouclier du Nord (Tarcza Północy, założona w 1870 roku). Krótki okres pracy lóż 1805-1810 przyniósł pokaźny dorobek poetycki; zachętą do podjęcia produkcji poetyckiej były zapewne wzory lóż niemieckich, ale utrwalenie tej produkcji jest indywidualną zasługa przyszłego nauczyciela Chopina, Józefa Elsnera.

\section{Pieśni wolnomularskie Józefa Elsnera}

W sierpniu 1810 roku Elsner rozesłał lożom drukowany prospekt, w którym czytamy między innymi:

Wszystkie loże we wszystkich językach mają zbiorek pieśni wolnomularskich śpiewanych przy rozmaitych okolicznościach i obrządkach swego zakonu. Niżej podpisany, czyniąc zadość tylokrotnie oświadczonym chęciom BB. Towarzystw Polskich, przedsięwziął wydać niniejsze dzieło w języku polskim. Zbiór ten zawiera kilkanaście hymnów, pieśni i innych śpiewów przez różnych BB. Poetów naszych wypisanych. Książka in $8^{\circ}$ maiori ma piękny papier, wybornym charakterem jest drukowana, w końcu zıajduje się kilka piosenek w języku francuskim i niemieckim, piękny i stosowny kopersztych zdobi toż dzieło. Oddzielna ksiązka, zawierają- 
ca nuty muzykalne tychże pieśni stychowane i urządzone na pianoforte i śpiew, dołączy się do pierwszej. Nizej podpisany z chęci jedynie uczynienia przysługi lożom ojczystym żadnego nie wyciąga zarobku, żądałby mieć znaczny zwrócony wydatek. Tak książka z poezją, jako i z muzyką kosztować będą czerwony złoty jeden w złocie. Obadwa dzieła ukończone będą przed św. Janem letnim ${ }^{30}$.

Elsner wywiązał się z podjętego zobowiązania i wydał anonimowo, nawet bez podania roku niewielki, 4)-stronicowy zbiorek 24 pieśni polskich, 3 francuskich i 3 niemieckich.

Józef Elsner, znany przede wszystkim jako kompozytor, dyrektor opery i konserwatorium, jest dla wolnomularstwa polskiego postacią bardzo zasłużoną. Urodzony w 1769 roku, kształcil się w Warszawie, a następnie studiowal medycynę w Wiedniu, gdzie, suponując z jego znajomości masońskich pieśni Mozarta, zetknął się może z wolnomularstwem. Zwróciwszy się ku muzyce, był przez pewien czas pierwszym skrzypkiem w Brnie, a następnie dyrektorem opery we Lwowie, skąd Bogusławski sprowadził go w 1799 roku do Warszawy, powierzając kierownictwo opery warszawskiej. Doprowadzil do utworzenia w 1821 roku Konserwatorium i byl jego dyrektorem do czasu zamknięcia uczelni w 1831 roku. Zmarł w roku 1854. W wolnomularstwie osiągnął najwyższy stopień, VII, Kawalera Różanego Krzyża, był czlonkiem Najwyższej Kapituły, członkiem honorowym wielı lóż, Rachmistrzem Wielkiego Wschodı. Zasłużył się przede wszystkim komponowaniem muzyki do pieśni masońskich, zarówno polskich, jak i niemieckich. Zajęcie się wydaniem pierwszego zbiorku pieśni jest więc tylko jednym z dowodów jego żywej działalności wolnomularskiej.

Układ pieśni w zbiorku jest następujący:

I. I Iynı przy otwarciu loży. Poezja Boguslawskiego, muzyka Mozarta.

II. Pieśń Hotd Napoleonou'i. Pierwszy raz śpiewana w loży Świątynia Mądrości XII 5806. Muzyka Elsnera.

III. Pieśń przy otwarciu loży adopcyjnej sióstr. Poezja Osińskiego, muzyka Elsnera.

IV. Śpiewka o wesołości w loży stołowej. Poezja Osińskiego, muzyka Elsnera.

V. Pieśń do BB. Wojowników. Poezja Drozdowskiego, muzyka Elsnera. VI. Pożegnanie BB. Wojskowych, gdy pierwszy raz wychodzili z Ojczyzny do Francji 5807. Poezja Drozdowskiego, muzyka Elsnera.

VII. Pieśń Pogarda zbrodni przełożona z francuskiego. Poezja Drozdowskiego, muzyka Elsnera.

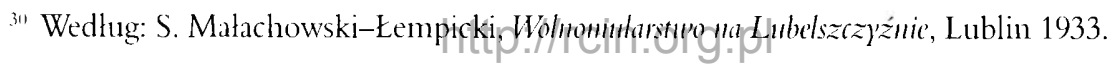


VIII. Hymn na uroczystość św. Jana przy pierwszym prezydowaniu w toż Święto Świątyni Mądrości. Poezja Drozdowskiego, muzyka Elsnera.

IX. Podróż BB. Czeladników. Poezja Adamczewskiego, muzyka Elsnera.

X. Hymn przy pierwszym otwarciu Świątyni Mądrości śpiewany 1805. Poezja Dmuszewskiego, muzyka Elsnera.

XI. Podróż BB. Czeladników. Poezja Adamczewskiego, muzyka Elsnera.

XII. Pieśń przy rozdawaniu jałmużny. Poczja Bogusławskiego, muzyka Stefaniego.

XIII. Pieśń w tymże celı jak przeszła. Poezja Bogusławskiego, muzyka Cherubiniego.

XIV. Łańcuch kończący lożę. Poezja Dmuszewskiego, muzyka zwyczajna.

XV. Pieśń loży adopcyjnej. Poezja Osińskiego, muzyka Mozarta.

XVI. Pieśń przy otwarciu loży. Poezja Wężyka, muzyka Elsnera.

XVII. Hymn śpiewany w dzień Imienin N. P. B. Axamitowskiego, mistrza loży Polacy Zjednoczeni 5 IV 1810. Poezja Dmuszewskiego, muzyka Elsnera.

XVIII. Śpiew historyczny na dzień imienin Różnieckiego i pierwsze ustalenie znaku loży Polacy Zjednoczeni 3 V 1810. Poezja Molskiego, muzyka Elsnera.

XIX. Śpiewka o wesołości. Poezja Wężyka, muzyka Elsnera.

XX. Duetto żałobne. Poezja Dmuszewskiego, muzyka Elsnera.

XXI. Duetto do mistrzów loży Świątyni Izis. Poezja Dmuszewskiego, muzyka Elsnera.

XXII. Sekstet do króla. Poezja Osińskiego, muzyka Elsnera.

XXIII. Hymn śpiewany na pierwszej loży stołowej Polacy Zjednoczeni. Poezja Dmuszewskiego, muzyka Elsnera.

XXIV. Pieśń ogólna dla wszystkich lóż. Poezja P’ękalskiego, muzyka Elsnera.

Przytoczylem tak dokładny spis pieśni, aby zorientować czytelnika, iż zestaw utworów jest nader różnorodny. Spotykamy nie tylko pieśni okolicznościowe pisane na dzień otwarcia loży czy imienin mistrza, lecz również pieśni pisane z myślą o rytuale masońskim. Jest pieśń na otwarcie loży, jest pieśń lańcuchowa, są pieśni towarzyszące zbieraniu jałmużny czy „podróży” czeladników. Jest pieśń żałobna, są dwie pieśni bankietowe i dwie pieśni do lóż adopcyjnych. Większość więc ważniejszych uroczystości, przy których przewidziano śpiewanie pieśni, jest w zbiorku uwzględniona, i aczkolwiek układ utworów nie wskazuje, by pod tym kątem zbiorek układano, to już same tytuly pieśni świadczą, iż Elsnerowi udało się wydać zbiorek dorównujący tym, o których pisal w prospekcie: 
wszystkie loże we wszystkich językach mają zbiorek pieśni wolnomularskich śpiewanych przy rozmaitych okolicznościach i obrządkach swego zakonu.

Zestaw autorów przynosi kilka nazwisk dobrze znanych w historii naszej literatury. Ze względu na wysoką rangę zarówno w ówczesnym świecie literackim, jak i wolnomularstwie, spośród autorów warto przede wszystkim wymienić Ludwika Osińskiego. W roku wydania zbiorku 35-letni Osiński był długoletnim już sekretarzem Towarzystwa Przyjaciól Nauk (od roku 1804), wydawcą „Pamiętnika Warszawskiego” (1809-1810), a sławę literacką gruntowały najsłynniejsze jego poezje Oda do Kopernika (1808) i Wiersz na pou'rót zwycięskiego wojska do stolicy (1809). Czekała go jeszcze kariera dyrektora teatru (1814-1830) i profesora literatury powszechnej na Uniwersytecie Warszawskim (1818-1830). W roku 1806 wstąpil do loży Świątynia Mądrości, osiągając z czasem najwyższy, VII stopień Kawalera Różanego Krzyża i piastując w wolnomularstwie szereg godności: był Mistrzem Katedry Świątyni Izis, Archiwistą, a następnie dlugoletnim Wielkim Mówcą Wielkiego Wschodu, członkiem Najwyższej kapituly i członkiem honorowym wielu lóż. Szczególnie godna podkreślenia jest jego działalność jako Wielkiego Mówcy. Zachowane w Archiwum Głównym Akt Dawnych liczne mowy Osińskiego są nie tylko przykładem krasomówstwa, mogącego fragmentami równać się ze stylem Stanisława Kostki Potockiego, lecz również dowodzą zaangażowania się autora w organizacyjne sprawy związku: przyłączenia do Wielkiego Wschodu lóż zależnych od Berlina, wznowienia prac wolnomularskich po upadku Księstwa, opracowania nowych ustaw itp.

Z trzech utworów Osińskiego zamieszczonych w zbiorku należy przede wszystkim przytoczyć Sekstet do króla:

Królu! Nie my tylko sami

Doznajem tego wesela,

Granica kraje rozdziela,

Bracia się łączą sercami.

Przyjm zamiast potęgi znaków

Prostą, lecz drogą ofiarę,

Dwie dawne cnoty Polaków:

Miłość i niezłomną wiarę.

Utwór ten jest bardzo dobrym przykładem, iż twórca o pewnej indywidualności poetyckiej z powodzeniem wykraczał poza okazjonalno-rytualne ramy masońskich utworów.

Śpiewka o mesotości, charakterystyczna dla pieśni śpiewanych w loży stołowej, chwaląc wesolość: 
Niech kto w jakim zechce względzie

Różne przymioty ocenia,

Lecz wesołość zawsze będzic

Pierwszym darem przyrodzenia -

każe nie zapominać o mularskich cnotach:

Nie zna szczęścia mularz prawy,

Jeśli go z biednym nie dzieli.

Wznieśmy cierpiącą niewinność,

Którą bliska zguba trwoży,

Niechaj nasza dobroczynność

Liczbę wesołych pomnoży.

W trzeciej pieśni: „W tej skromnej prawdy świątyni” brak polotu i oryginalności poezji Osińskiego staje się chwilami rażący:

Pod każdym świata klimatem

Cnotliwy jest naszym bratem,

Lecz zbrodzień niech stad ucieka,

Bo lańbi imię czlowieka.

Franciszek Wężyk (1785-1862) rozpoczynał dopiero karierę literacką. Tłumaczył już między innymi Sofoklesa (1804), Wergiliusza (1804), Schillera (1808), ale zarówno Barbara Radziu'ittóu'na, jaki i rozprawa $O$ poezji dramatyczncj byly w przygotowaniu. a dramaty i powieści historyczne miały się ukazać dopiero za lat kilkanaście.

Nie wiemy, do jakiej loży Wężyk należał, ale akta Najwyższej Kapituły dowodzą, iż osiągnął stosunkowo wysoki, piąty stopień wtajemniczenia. Dwa lata (1811-1812) Wężyk pehnił godność Wielkiego Sekretarza Wschodu, a w roku 1813 jego nazwisko spotykamy wśród kandydatów na Wielkich Urzędników; prawdopodobnie jednak wyjazd do Krakowa odsunął go od wyższych urzęéów w wolnomularstwie.

Oba zamieszczone w zbiorku utwory Wężyka są wyraźnie inspirowane przez masońską poezję niemiecką.

Pieśń „Precz stąd, slużalce niecnoty” jest wiernym naśladowaniem zamieszczonej w znanych mi zbiorach niemieckich pieśni „Hinueg, wer von Geu'alt und Raube”. Naśladowanie zupełnie zresztą udane i wolne od dosłowności thumaczenia:

Precz stąd, służalce niecnoty,

Precz, cudzej stawy morderce,

I wy, których twarde serce

Na jęk wdowy i sieroty! 
Nim przestąpiemy te progi,

Zrzucajmy światowe blaski,

Wygładźmy z serca niesnaski

I powściągnijmy nałogi.

Bardzo interesująca jest Śpieu’ka o wesotości. Już pierwsze dwa wersy: „O radości, drogi darze, / Której źródlo w samym niebie" - każą się domyślać inspiracji tego utworu przez Schillerowski Hymu do radości. Tematyka utworu pozwala na podtrzymanie tego domysłu. Nie mamy do czynienia z tłumaczeniem czy naśladowaniem $\mathrm{H}_{y^{\prime \prime m}-}$ $m !$, ale utworem posiadającym z wierszem Schillera pewne podobieństwa; możliwe, iż

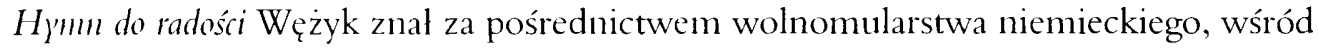
którego utwór ten był bardzo popularny.

Oto kilka strof ze Śpicuki Wężyka:

Cieszyć smutek, slodzić mękę,

Czynami radę podpierać,

Nieść potrzebie wsparczą rękę,

Upadłych nędzy wydzierać,

Oto wielkie przeznaczenie,

Oto szczęście jest prawdziwe,

Oto są czyste strumienie,

Skąd czysta rozkosz wypływa.

Twych dziś wszechwładnych wyroków,

Twojej wzywamy opieki,

Stap tu na skrzydlach obłoków

I mieszkaj z nami na wieki!

Jedna trzecia utworów zamieszczonych w zbiorku wyszła spod pióra Ludwika Dmuszewskiego (1777-1847). W chwili wydania zbiorku przyszly dyrektor teatru (1827-1832) i redaktor „Kuriera Warszawskiego” (od roku 1822) grywał amantów i śpiewal partie tenorowe w trupie Bogusławskiego oraz pisal i przerabial sztuki, których nazbierało siç w końcu około stu pięćdziesięciu. W wolnomularstwie osiągnął VII stopień. Jego nazwisko spotykamy w lożach: Zum Goldenen Leuchter, Świątynia Mądrości i Świątynia Izis. Na początku lat dwudziestych był Dyrektorem Harmonii Wielkiego Wschodu i czlonkiem kilku lóż. Wspominaliśmy już wiersz Dmuszewskiego „O święto! Dniu uroczysty”, wydrukowany z okazji odśpiewania go na pierwszej polskiej loży Zlotego Lichtarza. W zbiorze Elsnera utwór ten zaopatrzony jest w informację, iź śpiewano go przy pierwszym otwarciu loży Świątynia Mądrości, a okazjonalny wers o lączących się Sarmatach i Germanach zastąpiony jest zwrotem: 
Dziś łączy węzeł wieczysty

Różne ludy, różne stany.

W tym sześciostrofowym utworze opisywane są cechy i cele związku mularskiego. Charakterystyczne i warte przytoczenia są dwie strofy:

Cnota, chcąc, by nierozdzielnie

Czcily ją wszystkie narody,

Dala nam tę cllubną kielnię

W przybytku chwały i zgody.

Gdzie rozum osiadł na tronie,

Szczęśliwi przy tej potędze

Gardzą zbrodniarzem w koronie,

Wielbią poczciwych w siermiędze.

Zgrabna i udana jest pieśí łańcuchowa (nr XIV):

W tym świetnym przyjaciól gronie

Łączcie się, bracia swobody,

Podajcie życzliwe dłonie

Na znak przyjaźni i zgody.

Inne utwory Dmuszewskiego nie wykraczaja poza poprawne i przeciętne rymowanie, zakłócone czasem zwrotami typu: „pod pukiem twego młota” (pieśń nr XXI) czy: (dzień, co lączy) ,moralno wolnych Mularzy” (pieśń ur XXIII).

Wojciech Bogusławski (1757-1829), znany przede wszystkim jako twórca teatru narodowego, zarówno na polu literatury, jak i wolnomularstwa specjalnej roli nic odegrał. Chcąc zasilić skąpy polski repertuar, napisał około osiemdziesięciu sztuk, głównie przerabiając i thumacząc utwory obce. $Z$ wolnomularstwem zetknął się jeszcze w XVIII wieku w Dubnie, w 1805 roku afiliowany był do loży Świątynia Mądrości w stopniu mistrza. Trzy wierszyki są właściwie jedynym przejawem jego masońskiej działalności.

Hymn przy otwarciu loży: „W tym tu przybytku świętym” jest tłumaczeniem niemieckiej pieśni zamieszczonej w Vollstaendiges Gesangbuch: "In diesen heiligen Hallen”. W prostych rymach pieśí głosi, iż w związku mularskim panıje przyjaźń i zgoda, a nie ma miejsca dla zemsty i zdrady:

W tych świętych miejsc obwodzic,

Gdzie człowiek kocha człeka,

Nie slychać o niezgodzie,

Bo zdrada stąd ucieka. 
Z dwóch pieśni jałmużniczych, jedna, krótki sześciowiersz, nie posiada charakteru wyraźnie masońskiego, i mogła być zaliczona do pieśni wolnomularskich jedynie dla akceptacji zawartej w niej myśli:

Nie ci nam świadczą, którzy są bogaci,

Nie ci, co przymus lub interes mają,

Bo pierwsi dają, co zdarli z swych braci,

Drudzy do laski wzgardę przylączają,

Lecz ten nam daje dar ze wszech miar drogi,

Kto z serca daje, choć sam jest ubogi.

W drugiej pieśni: „O Opatrzności! Pomoc Twoja” zwrot do Opatrzności, zastępowanej w wolnomularstwie „Wieczną Istnością” lub „Najwyższym Jestestwem”, mógłby również wskazywać na „Światowe” pochodzenie utworu. Ostatnia jednak strofa nawiązuje bezpośrednio do wolnomularstwa:

By kiedyś prochu garść mojego

Gdy ujrzy w grobie czlowiek tkliwy,

Zawołal: Mularz ten poczciwy

Ratował w nędzy bliźniego.

Z okazji omawiania pieśni Bogusławskiego warto zwrócić uwagę na nazwiska kompozytorów, których muzyka pieśniom tym towarzyszyła. Wolfgang Amadeusz Mozart był wolnomularzem bardzo czynnym w lożach wiedeńskich i skomponował wiele masońskich pieśni; Jan Stefani, koncertmistrz Stanisława Augusta i kapelmistrz opery, autor muzyki Krakouviakón' i górali był członkiem warszawskiej loży Braci Polaków Zjednoczonych; muzyka Luigi Cherubiniego, znanego ówczesnego kompozytora operowego, musiała trafić do masońskich pieśni raczej poprzez operę warszawską niż przez wolnomularstwo.

Jan Drozdowski (1759-1810), komediopisarz, znany jest przede wszystkim jako autor Literata z bied, i Bigosu hultajskiego oraz jako tłumacz wolterowskiej Meropy. W 1806 roku wstąpił do loży Świątynia Mądrości, a w 1811 Świątynia Izis uczciła jego pamięć w obchodzie żałobnym.

Z czterech wolnomularskich utworów Drozdowskiego żaden nie wyróżnia się polotem.

W hymnie do Wielkiego Budownika śpiewanym w uroczystość świętojańską poeta podkreśla przede wszystkim integracyjne walory wiary:

Tyś jest, którego potęga

W nieprzeliczone ogniwa,

Jakich żadna moc nie zrywa,

Obce sobie ludysprzega 
Tłumaczona z francuskiego pieśí Pogarda zbrodni nie jest utworem wyraźnie masońskim, a Drozdowski gubi się w zawilościach stylu oryginału:

Przebaczających znajduje ubogi,

Choć oziębłością wstręt okaże w twarzy,

Ma ich ciemnota, zapęd, sędzia srogi,

I ten, komu się nie chcąc chybić zdarzy.

Z dwóch pieśni poświęconych „braciom wojownikom” trzeba wsponnieć o pieśni żegnającej żohnierzy wyruszających w 1807 roku z wojskami napoleońskimi. Charakteryzuje ona nie tylko masońskie nastroje towarzyszące wkroczeniu wojsk napoleońskich na ziemie polskie:

Pod wielkim Napoleonem

Uczmy się, jak znosić znoje,

Kochać sławę, gardzić zgonem

I ogniska bronić swoje.

Jako dokument nastrojów znacznie ciekawsza jest jednak pieśń Hołd Napolconouri, jedyna w zbiorku pieśń anonimowa, śpiewana jak głosi tytul w grudniı 1806 roku w loży Świątynia Mądrości:

Co za opatrzność nad nami!

Ojczyzna ma być dźwigniona,

Witajmy czulości łzami

WIELKIEGO NAPOLEONA!

Dni szczęśliwe odtąd liczem,

Jak Stworzyciela rzekł słowy

"Lat dwanaście byłeś niczem,

Polsko, nadam Ci byt nowy".

Zlóżmy mu wdzięczności pienia,

Niech żyje Polski obrona,

Niech czczą późne pokolenia

WIELKIEGO NAPOLEONA!

Gdy przypomnimy sobie słowa Potockiego o wolnomularstwie jako jedynej ostoi w niepewnej i zmiennej sytuacji politycznej, dowodem, iz przekonanie takie było powszechnym, będzie Ś picu historyczny' wykonany w loży Braci Polaków Zjednoczonych w 1810 roku w rocznicę uchwalenia majowej konstytucji:

Gdy narodowe wymazal święto

Świętokradzki gwalt mocarzy, 
Gdy na trzy kraje kraj nasz rozcięto,

Został duch wolnych mularzy.

Autor Śpicu'u, brat Marcin Molski (1751-1822) cieszył się w początkach XIX wieku szeroką sławą poetycką, którą przyniosły mu setki okolicznościowych wierszy i wierszyków poświęcanych wszystkim znaczniejszym osobistościom.

Podróz BB. Czeladnikóu Adamczewskiego jest tumaczeniem bardzo popularnej niemieckiej pieśni: „Freut, Bruder, euch auf euren Reisen” drukowanej po niemiecku również w naszych lożach. Autorem tłumaczenia jest komediopisarz Jakub Adamczewski (1763-1813), członek Towarzystwa Przyjaciól Nauk i regent kancelarii Rady Stanu. W 1802 roku na warszawskiej scenie grana była jego komedia Stary bezżeniec, a drukiem ukazał się wybór powieści moralnych i romansów oraz wybór podróży. W wolnomularstwie osiągnął stopień Mistrza, w roku 1805 byl członkiem loży Świątynia Mądrości, a w roku 1811 loży Świątynia Izis.

Pieśn ogólna dla w'szystkich lóż brata Pękalskiego charakteryzuje zasady związku masońskiego:

Mularz powierzchowność ma za nic

I gardzi powabem zbytku.

Przed mocnym klęknąć nie zdoła,

Ani go korzyść nie wzbudzi,

By dumnym uniżył czoła,

Bo zna, co jest godność ludzi.

Rzucił na nas świat zrzenice

Pełen przesądnej ciemnoty,

Kryjem w lożach tajemnice,

Lecz chcemy słynąć przez cnoty.

Autor pieśni, Wojciech Pękalski, w spisach lożowych zapisany jest jako „prokurator sądu". Był członkiem loży Zum Goldenen Leuchter, następnie Świątyni Mądrości i Świątyni Izis, w której pełnil urząd Mówcy i osiągnął VII stopień Kawalera Różanego Krzyża.

Kilka słów trzeba poświęcić pieśniom niemieckim i francuskim załączonym w zbiorku.

Pieśí z muzyką Elsnera: „O selig war diese Pilger-leben / An meines Freundes Arm durchlebt”, jak i pieśń I Ierholbsa z muzyką Mozarta: „Wer tief gerïhrt bei fremden Leiden”, zamieszczone są w Iollstandiges Gesangbuch. Pieśń brata Laudiusa z muzyka Elsnera: „Wer mit scheten Blick hier eintritt..." nie jest mi znana.

Wśród pieśni francuskich znajdujemy zamieszczony już w zbiorku brata Naudot i często przedrukowywany hymu: "Frères et Compagnons / De la Maçonnerie" oraz spo- 
tykaną w zbiorku wydanym w Paryżu w 1752 roku pieśń: „Parmi cette société / Régne une douce volupté".

Trzecia pieśń francuska: „Chantons du sage / De vrai bonheur” nie jest mi z innych zbiorków znana.

Jak widzimy z zestawu nazwisk autorów, prezentowane przez Elsnera utwory powstały głownie w środowisku loży Świątynia Mądrości, i to dzięki przynależeniu do nicj ludzi znanych z „światowej” twórczości literackiej. Ich masońskie utwory czynią zbiorek ten szczególnie interesującym dla historyka literatury. Zbiorek Elsnera wyznacza początek rozwoju polskicj poezji masonískiej. Zakończony został okres, w którym zarówno wydarzenia polityczne, jak i słabości wewnętrzne utrudnialy prace masońskie. Po okresie tym, trwającym przeszło siedemdziesiąt lat, nastąpić miał krótki, tylko dziesięcioletni okres pełnego rozkwitu wolnomularstwa w Polsce. Jednym z przejawów i konsekwencji tego rozkwitu jest masońska poezja.

\section{Rozdział 5}

\section{Rozkwit wolnomularstwa polskiego i jego poezji}

\section{Wielki Wschód 1810-1821}

Okres rozkwitu wolnomularstwa polskiego rozpoczyna akcja stworzenia z Wielkiego Wschodu silnego organizmu władzy w pełni kontrolującego powstawanie i dziatalność lóż na terenie Księstwa Warszawskiego. Przede wszystkim Wielki Wschód przystępuje do podporządkowania sobie lóż zależnych od lóż berlińskich, co jednak nie obywa się bez oporów - Wielki Mówca Osiński kilkakrotnie grozi zamknięciem przez władze cywilne niesubordynowanych lóż. Pod koniec roku 1811 do Wiclkiego Wschodu należy już jednak 12 lóż z Warszawy, Krakowa, Poznania, Kalisza, Lublina, Bydgoszczy i Radomia.

W dążeniu do zapewnienia reaktywowanemu Wielkiemu Wschodowi odpowiedniego prestiżu, poezja towarzyszy jego pracom od początków działalności. Kiedy 21 czerwca 1810 roku reprezentanci 6 lóż składających Wielki Wschód wybrali Wielkim Mistrzem prezesa Rady Stanı Ludwika Gutakowskiego, „Bracia Amatorzy i bracia Artyści różnych lóż pracujących pod Wschodem Warszawy" wykonali Śpicut z okoliczności u'yboru Wielkiego Mistrza W. Wschodı Narodouego Franciszka Wężyka, do muzyki Józefa Elsnera.

Utwór rozpoczyna Chór:

Czciciele prawdy i cnoty,

Pełnią się wasze nadzieje,

Zniknęly głuche ciemnoty

I światło znowu jaśnieje. 
O czasach owej "głuchej ciemnoty” opowiada Jeden głos: „Brzemienne ogniem i gromem chmury”. Wtóruje mu Imny głos: „Wy, co w szlachetnym zawodzie”. Następnie do nowo obranego mistrza zwracają się Du’a gtosy:
Mistrzu, do pierwszego młota
Wezwany przez braci zgodę,
Rządź sercami tą potęgą
Jaką w naszym masz zakonie.

Wreszcie do zgromadzonych braci zwraca się Jeden gtos z chórem: „Bracia, których $w$ to schronienie".

W porównaniu z pieśniami ze zbiorku Elsnera, utwór ten wyróżnia się przede wszystkim formą — kantata o skomplikowanej wokalizacji odznaczała się bardziej uroczystym charakterem niz solowa czy chóralna pieśń.

W grudniu 1811 roku, umiera nagle Wielki Mistrz Gutakowski. Na odbytej w styczniu 1812 roku uroczystej loży żałobnej wygłoszono mowy po polsku, francusku, niemiecku, oraz odśpiewano polską i francuską elegię, a protokół posiedzenia, mowy i elegię, ogłoszono drukiem i rozesłano lożom.

Anonimowy autor polskiej elegii w ponad 100 wersach opiewa zasługi Wielkiego Mistrza, i wyraża przypuszczenie, iż po śmierci patronować będzie pracom towarzystwa, ale...

A jeżli kiedy zbrodnia zohydzona

Weźmie hołd należny cnocie

Wydrzyj się wtenczas z braci twoich grona,

Dozwól im ginąć w ciemnocie.

Elegia francuska brata Bignon, rezydenta francuskiego w Warszawie jest naśladowaniem elegii polskiej; Louis Pierre Edouard Bignon nie zgodzil się na drukowanie swego utworu i znamy go tylko z rękopisu:

Il n'est plus home juste, honncur de la Patrie de l'Etat renaissant le premier citoyen.

W marcu 1812 roku wybory Wielkiego Mistrza czci anonimowy poeta utworem:

Cieszmy się bracia, cieszmy na nowo,

Dzięki powinne wam, nieba.

Radość poety jest o tyle prorocza, iż rządy nowo wybranego Wielkiego Mistrza Stanislawa Kostki Potockiego okażą się dla wolnomularstwa polskiego bardzo szczęśliwe. Potocki zachowa władzę Wielkiego Mistrza aż do roku 1820, ciesząc się przez cały okres jej trwania powszechnym szacupkienz i zaufaniem. 
W jego postaci bardzo wyraźnie syntetyzuje się postawa oświeconego polityka z postawą ideologa-masona najwyższych stopni. Jego działalność polityczna, literacka i wolnomularska zawsze się zbiegały. Zasłynąwszy na sejnie 1782 roku wspaniałymi mowami, w 1784 roku wyglasza pierwszą orację jako Wielki Mówca Wielkiego Wschodu, orację będącą jego debiutem literackim.

Sprawowanie rządów Wielkiego Mistrza lączy z urzędami Prezesa Rady Stanu w Księstwie i Ministra Wyznań i Oświecenia w Królestwie, a także z działalnością "Świstka krytycznego" i z pisaniem Podróży do Cicmnogrodn.

W literackiej działalności Potockiego nietrudno znaleźć nie tyle wpływy ideologii masońskiej, ile jej twórcze wykorzystywanie. Jest jednak rzeczą charakterystyczną, iz w kilku rękopiśmiennych zbiorach wierszy, pisanych dla zabawy i przyjemności, nie ma utworu nawiązującego do wolnomularstwa, natomiast nawiązań tych nie brak w Podró$\dot{z} y$ do Ciemnnogrodı. Dla Potockiego działalność masońska wiązała się przede wszystkim z walką z obskurantyzmem i ciemnotą, a nie okolicznościowymi, przyjemnościowymi wierszykami. Jedynymi utworami, jakie dla potrzeb związku tworzył, były mowy, wygłaszane przeważnie na posiedzeniach Wielkiego Wschodu $1^{31}$.

Ogłoszenie nowego Wielkiego Wschodu pod mlotkiem Potockiego otwiera okres stabilizacji wewnętrznej związkı. Roczną przerwę w pracach lożowych wprowadzi tylko nagły zwrot sytuacji politycznej w latach 1813-1815, upadek Napoleona i utworzenie Królestwa Polskiego; wolnomularze, korzystając jednak z liberalnego nastawienia Aleksandra, nader szybko dostosowują się do sytuacji: zamiast Napoleona nazywają Aleksandra swym ojcem i protektorem, i loże wznawiają prace zgodnie z zarządzeniem Wielkiego Warsztatu z kwietnia 1814, a wiec jeszcze przed rozpoczęciem Kongresı Wiedcnískiego. Ilość lóż z 13 na początku roku 1816 wzrasta do $20 \mathrm{w}$ roku następnym, a w roku 1820 na Wielki Wschód składają się 44 loże, z tego 8 kapitularnych (3 wyższe i 5 niższych). Wzrost liczby czlonków, a co za tym idzie, siły poszczególnych lóż, jest również znaczny i niczym nie zakłócany, siłę natomiast Wielkiego Wschodu i całego wolnomularstwa zaczynają na przełomie lat dwudziestych rozbijać spory, które poza charakterem wewnątrzzwiązkowym (spór o wprowadzenie wyższych stopni, tzw. templariuszowskich, głoszących obalenie tiary i korony, spór o przygotowanie i przyjęcie nowej ustawy związkowej regulującej dogmatyczną władzę związku) miały niewątpliwe powiązania z sytuacją polityczną Królestwa. Powstanie różnego charakteru związków tajnych, między innymi wolnomularstwa narodowego Łukasińskiego oraz tzw. sprawa kaliszan wzbudziły nieufność Aleksandra i Wielkiego Księcia Konstantego, i jakoby spowodowały dywersyjna robotę szpiegów rosyjskich w łonie samego związku, a przede wszystkim wśród jego najwyższych władz. 
O pomaganie władzom carskim w osłabianiu i rozbijaniu siły związku posądzany jest między innymi Namiestnik Wielkiego Mistrza, a po ustąpieniu Potockiego Wielki Mistrz, gen. Aleksander Różniecki.

Rozłam i spory o ustawę związkową przerwal ukaz carski z sierpnia 1821, zakazujący działalności wolnomularstwa, i uzupełniony październikowym ukazem zmuszającym członków lóż do podpisania deklaracji, iż nigdy do związków masońskich ani w kraju, ani za granicą należéc nie będą.

Okres wewnętrznej stabilizacji lóż w latach 1812-1821 wydał znaczną ilość utworów poetyckich. Okres ten charakteryzuje się przede wszystkim zdecentralizowaniem produkcji literackiej; już nie tylko loże warszawskie i znani poeci tworzą kompozycje masońskie, powstają one przede wszystkim w lożach pozawarszawskich i pod anonimowymi bądź zupelnie nieznanymi w historii literatury piórami.

\section{Rozdział 7}

\section{Działalność poetycka i wydawnicza Tadeusza Wolańskiego}

\section{Sylwetka Tadeusza Wolańskiego}

Domysłom jedynie możemy pozostawić tłumaczenie zarówno zainteresowań literackich brata Tadeusza Wolańskiego z loży Doskonale Zjednoczenie na Wschodzie Włocławka, jak i jego zapałów i możliwości wydawniczych. Skoro znamy nazwisko wydawcy zbiorków, skoro wiemy z ich tytułów, iż przeznaczone była dla wszystkich lóż pracujących pod Wielkim Wschodem, skoro wreszcie zawartość zbiorku nosi wyraźne piętno osobistych zainteresowań Wolańskiego, to środowisko loży, w której powstał zbiorek, może nas mniej interesować, a przede wszystkim winniśmy zwrócić uwagę na postać wydawcy. Niestety, zarówno o Tadeuszu Wolańskim, jak i loży Doskonałe Zjednoczenie wiemy niewiele, a konfrontacja skąpych wiadomości czerpanych z tytulów zbiorków, dokumentów masońskich oraz innych źródeł historycznych nakazuje ostrożność w koniecznych próbach ustalenia minimum wiadomości o wydawcy i autorze zbiorku najbardziej interesującego w naszej poezji masońskiej.

Tadeusz Wolański, herbu Przyjaciel, urodził się w 1785 roku w Szawłach na Żmudzi ${ }^{32}$. Był synem Jan z Wolan, kilkakrotnego posła do dworu szwedzkiego i Julianny de Buch. W 1804 roku odbywa podróż do Anglii, Szwecji, Holandii i Francji, a w 1806 wstępuje do pułku Wincentego Krasińskiego, a następnie 6 pułku ułanów. Mianowany przez księcia Poniatowskiego porucznikiem, skierowany zostaje do Torunia, do sztabu Wołczyńskiego, gdzie wkrótce awansuje do stopnia kapitana. Biorąc udział w obronie

\footnotetext{
32 Wiadomości o życiu Wolańskiego znalazłem przede wszystkim w pracy Stanisława Karwowskiego Historia Wiatkiegro Ksiçstu'a Poznańskicgo Pozmań 1918.
} 
Torunia, otrzymuje krzyż Legii I Ionorowej i zostaje komendantem toruńskiej twierdzy. W czasach pobytu Wolańskiego w Toruniu rozpoczyna działalność loża Doskonale Zjednoczenie, której zalożycielem, jak wynika z tytułów zbiorków, był Wolański.

Loża ta powstala w okresie kształtowania się dopiero władzy narodowej Wielkiego Wschodu i utrzymywała kontakty bezpośrednio z Najwyższą Kapitułą, a jej reprezentantem w Warszawie był jeden z najwybitniejszych polskich mularzy Eliasz Aloy ${ }^{33}$.

Wolański musiał zetknąć się z wolnomularstwem w wojsku, i zalożona przez niego loża grupowała prawdopodobnie również wojskowych. W Toruniu pracowała od 1793 roku zależna od Berlina loża Bicnenkorb; powstanie nowej polskiej loży Doskonalego Zjednoczenia wywołało szykany loży niemieckiej i skargi Doskonałego Zjednoczenia do Najwyższej Kapituly wspominające .,esprit de chicane et expressions les moins mesurécs".

W początkach 1811 roku Wolański zwraca się do Najwyższej Kapituly o uznanie posiadanego przez niego stopnia Kawalera Różanego Krzyża (otrzymanego widocznie poprzez mularstwo francuskie) i prawo udziclania wyższych stopni urzędnikom swej loży. Kapituła wstrzymała wyrażenie swej opinii na ten temat.

W listopadzie tegoż roku brat Wolański, były Mistrz Katedry Doskonalego Zjednoczenia, zajął swą prośbą całe posicdzenie Najwyższej Kapituły. Zwrócił się on o przyznanie mu prawa zakładania lóż przeznaczonych wyłącznie dla Żydów. Kapituła wyraziła uznanie dla wywodów „pełnycl erudycji i dobrych intencji”, ale prośbę odrzuciła, prosząc Aloya o szczegółowe wyjaśnienie Wolańskiemu powodów odmowy.

Kampania 1812 roku musiała wprowadzić zamęt w pracach loży; z Kapitulą koresponduje Mistrz Katedry Schutz, a dopiero w październiku 1812 roku z listem występuje znów Wolański jako Mistrz Katedry, przepraszając, iż jego nieobecność i „zbyt mała liczba braci po wyjściu wojska" przerwały prace. Jest to ostatni ślad masońskiej działalności Wolańskiego — po roku 1812 nie spotykamy jego nazwiska w żadnych dokumentach masońskich.

Wspomniany historyk (patrz przypis 81) podaje, iz Wolański, poślubiwszy baronównę Wilhelminę Schroeder, osiadł w Księstwie Poznańskim co zbiega się z informacją zawartą w zbiorku podającym adres autora: wieś Wróble koło Inowrocławia, Księstwo Poznańskie. Loża Doskonałego Zjednoczenia przeżywała w tym czasie kryzys, i Wielki Mówca Osiński skarży się w 1815 roku, izz nic nie wiadomo o pracach toruńskiej loży, a dopiero w kilka miesięcy później zawiadamia, iż „wkrótce loża Doskonałe Zjednoczenie, której polityczne stosunki nie dozwalały ze Wschodu Torunia do nas przynależéc, przenosząc w inne miejsce swój pobyt, przerwane prace rozpocznie".3. Miejscem tym był Włocławek. Trudno przypuszczać, czy Wolański brał udział w pracach loży, skoro

${ }_{33}$ Poszczególne wzmianki o korespondencji Doskonałego Zjednoczenia i Wolańskiego z Najwyższą Kapitułą zawarte są w AGAD Kanc. Nowos. 832, 833.

${ }^{3+}$ AGAD Mas. III $3 / 3$. 
mieszkał poza granicami Królestwa, wiemy tylko, iż osiadłszy w Księstwie Poznańskim, rozpoczął wszechstronną działalność naukową. Skala jego zainteresowań była bardzo szeroka: pisał prace o numizmatyce, archeologii, piśmie klinowym, zajmował siç astronomią, zoologią i botaniką, ogłaszał prace z historii Słowian oparte na własnych wykopaliskach, korespondowal z Lelewelem itp. ${ }^{35}$ Jednocześnie był radcą ziemiańskim powiatu inowroclawskiego i kilkakrotnie posłował na sejm Księstwa. Spotkałem się z opinią, iż na pracach Wolańskiego bardziej zaciążyła wyobraźnia autora niż rzeczywista wiedza i fakty. Zmarl w 1865 roku.

Zajmowanie się działalnością poetycką i wydawniczą wydaje się jeszcze jednym przejawem talentów i temperamentu Wolańskiego, lecz podobnie jak i jego praca naukowa, działalność ta nosi znamiona przypadkowości; ogłosiwszy w 1817 i 1818 roku udane masońskie zbiorki poetyckie, nie kontynuowal pracy literackiej, a w jego rękopisach odnaleźć można tylko napisany po niemiecku na "własny użytek" Podręcznik sztuki poctyckicj ${ }^{30}$.

Dopiero po kilkudziesięciu latach Wolański powrócił do twórczości poetyckiej, tłumacząc "wierszem ojczystym” jeden z dramatów Wiktora I Hugo: Tizba. Zalodia w' czterech oddziatach, na podstan'ie trajedyi francuskiej Andżelo tyran paduranski ${ }^{37}$.

Musimy zadowolić się tymi kilkoma wiadomościami i skoncentrować uwagę na najbardziej nas interesującym śladzie działalności Wolańskiego i loży Doskonalego Zjednoczenia: zbiorkach masońskiej poezji.

\section{Pieśni wolnomularskie na obchód uroczystości narodzin...}

Pierwszy zbiorek nie bardzo właściwie zasługuje na tę nazwę. Na sześciu kartach zawartych jest tylko pięć pieśni. Wydany jest za to z wielką okazałością: in folio, z kolorowymi obwolutami z symbolami masońskimi, drukowany ozdobną czcionką. Uroczystość, na jaką został przygotowany, tłumaczy zarówno skromną stosunkowo zawartość, jak i bogatą formę wydawnictwa. Są to Pieśni uolnomularskie na obchód urocz)'stości Narodzin Najjaśniejszego cesarza i Króla Aleksandra u'ygotou'ane na użytek lóż "Królestu'le Polskim przez Tadeusza Wolaniskiego mistrza katedry i założyciela spr[awiedliu'ej] i dosk [onatej] loży pod nazu'iskicm Doskonatego Zjednoczenia na Wschodzie Wtoctan'ka pracującej. R[oku] P[prau'dziu'ego] Ś [u'iatta] 5817 [1817] "'drukarni kamiennej Grassa Bantha i Komp "Wroctawiu.

Do wzmianek o holdowniczym stosunku polskich mularzy do Aleksandra, do ulotnych wierszy z wiernopoddańczymi wzmiankami dodajemy teraz zbiorek przygo-

\footnotetext{
35 Szereg ręckopiśmiennych prac naukowych Wolańskiego posiadała Biblioteka PAU-PAN w Krakowie. Drukowane wymienia Estreicher.

Katalog rękopisów Biblioteki PAU-PAN.

3. Gniezno 1863. Wedlug Estreicher
} 
towany — jak na to wskazuje ozdobna forma - specjalnie dla przypochlebienia się cesarzowi i zarazem umożliwienia lożom jego 40-lecia urodzin (Aleksander urodził się w 1777 roku).

W pięciu pieśniach zamknął Wolański chyba wszystkie nadzieje i hołdy nie tylko wolnomularzy, lecz jeszcze sporej części społeczeństwa Królestwa, związane z wstąpieniem na tron Polski liberalnego - jak wierzono - Alcksandra.

Zbiór otwiera utwór zręcznie naśladujący hymn God save the King:

O! Aleksandrze nasz,

Serce i życie masz

Poddanych Twych!

Przyjmij ofiarę tę,

Mularz uczucia swe

Tobie, Monarcho, dziś

Oddaje w hołd!

Dla Cię radosne tzy

Ronią, że wracasz Ty

Ojczyznę nam.

Mularze, wstańcie wy!

Niech przez trzy razy trzy

Ku niebu wznosi się

Wdzięczności głos.

W następnym utworze Wolański zwraca się do cesarza:

Ojcze Polaków, Aleksandrze wielki,

Światly, wspaniały i dobry bez miary;

Przed Twoją cnotą leżąc, naród wszelki

Czule Ci z serca przynosi ofiary.

Znowu powstały z grobu ponurego,

Twym berłem tknięte kunszta i nauki;

Coś dla Polaka uczynił sierotnego,

W wdzięcznej pamięci chować będą wnuki.

W trzeciej, najbardziej pompatycznej pieśni:

Śpiewam Królowi, co na Piasta tronie

Sercami ludu panując zasiada.

Wolański przypomina o opiece, jaka otacza Aleksander wolne mularstwo, ijest to znowu okazja do wyrażenia „dozgonnej wdzięczności”: 
Pod Jego tarczą, do tej świetnej sali

Hasłem braterskim zebrani mularze,

Śmiejąc się z groźnej fanatyzmu fali,

Prawdzie, mądrości, budują oltarze.

Zlóżmy hołd Jemu dozgonnej wdzięczności;

Byt nasz z rąk jego wzięliśmy jedynie;

Poświęćmy serca monarszej miłości -

Niechaj dla Króla krew Polaka płynie.

Czwarty utwór: "Co za Opatrzność nad nami! / Ojczyzna z grobu powstała” nie jest nam obcy. W 1806 roku w Świątyni Mądrości śpiewano utwór Hołd Napoleonou'i, zamieszczony następnie w zbiorku Elsnera. Zmieniwszy imię Napoleona na Aleksandra, usunąwszy jedną strofę i wprowadzając kilka zmian w pozostałych, stworzył Wolański zupełnie nowy wiersz, ciekawy jako dowód przystosowania utworu literackiego do zmieniającego się kontekstu historycznego (zob. cytaty z wersji z 1806 i 1817 roku na początku niniejszego artykułu).

Zmiana nastrojów w ciągu dziesięciu lat zamyka się, jak widzimy, nie tylko w zmianie imienia bohatera utworu, lecz i w zastapieniu „Polski obrony” — "głosem wiwatów”, a nastroju opuszczonej strofy — bierną wzmianką o „walecznych Sarmatach”.

W piątym, ostatnim utworze Wolański zachęca do wiwatów na cześć rodziny cesarskiej, skrupulatnie wymieniając wszystkich jej członków: „Palcie, mularze, Aleksandra zdrowie”; „Zdrowie Elzbiety palcie Aleksiewny”; „Dalej, za zdrowie Matki Cesarzowej”; ,Teraz, mularze, palcie Konstantemu”;

Żywo za zdrowie księcia Mikołaja,

Co obfitując w rycerskie przymioty,

Węzłem miłości niestarganym spaja

Rękę swą z ręką nadobnej Szarloty;

Dalej, mularze, nabijcie armaty -

Za zdrowie księcia wykrzyczcic Michała;

Wiwat Maryja, wiwat Katarzyna,

Wiwat, obydwie niechaj żyją Anny!

Strofa poświęcona Mikołajowi jest wystarczająco dobrym przykładem charakteru całego utworu: poza znaczeniem politycznym miał on chyba dla wolnomularzy tylko jedną poważną zaletę: jedenaście toastów do spełnienia.

Ten skromny zbiorek Wolańskiego jest jednym z nielicznych w całej naszej literaturze przejawów towarzyszących wstąpieniu Aleksandra na tron polski, nastrojów, które wspomnieniem polskiej tradycji / iredrębueściơraz nadzieją ich utrzymania różniły 
się od serwilizmu, jaki wśród części obywateli Królestwa wzbudziły policyjne rządy po 1820 roku.

\section{Pieśnik wolnomularski}

W rok po ukazaniu się Pieśni na obchód uroczystości narodzin... Wolański kontynuuje działalność literacką, wydając w 1818 roku znów we Wrocławiu Pieśnik u'olnomularski na użytek u'spaniatego Wielkiego Wschodu Narodourego i pracujacych pod jego Konstytucją láż regularnych "Królestu'ie Polskim. Mottem zbiorku jest czterowiersz Wolańskiego:

Zejdź z niebios wysokości, o nauko święta,

Niech się tknięte twym duchem ludzkie skruszą pęta,

A przed blaskiem jutrzenki i Twojej pochodni

Fanatyzm pierzchnie zbójczy, pelznie przemoc zbrodni.

Ilustracją tych słów jest miedzioryt przedstawiający postać kobiecą z pochodnią w ręku, rzucającą insygnia mularskie ku siedzącemu na skale człowiekowi, mającemu zawiązane oczy, a nogi i ręce skute kajdanami. Treść motta rozszerzona jest dwoma szczegółami: postać kobieca, owa święta nauka mularstwa, siedzi na orle w koronie, a bijące pioruny trafiają trójgłowego smoka.

Czystą spekulacją byłoby doszukiwanie się w tej alegorii jakichkolwiek aluzji patriotycznych, ale warto wskazać, iz aluzje takie można było znaleźć, a wolnomularstwo narodowe tlumaczące caly rytuał masoński w kategoriach walki z zaborcami i odrestaurowania Polski jest najlepszym przykładem, iż poszukiwania takie były czynione.

\section{Zakończenie}

\section{Znaczenie poezji masońskiej w literaturze polskiej}

Celem niniejszej pracy było przedstawienie zajwiska poezji masońskiej w Polsce. Zagadnienie znaczenia tej poezji w naszej literaturze jest tematem odrębnym i wymagającym innego sposobu opracowania, dlatego tez w pracy tej ograniczam się tylko do kilku ogólnie formułowanych sugestii.

Zjawisko poezji masońskiej jest w swym charakterze hermetyczne i dlatego trudno porównywalne z innymi zjawiskami literackimi, których cele, motywy powstania i sposób odbioru są zupelnie odrębne. $Z$ tych względów przy porównywaniu poezji masońskiej z równoczesnymi jej zjawiskami w polskiej litcraturze poezja ta może być oceniana jako marginalna i nieuczestnicząca w ksztaltowaniu się ówczesnych stanowisk i prądów teoretycznych.

Poezja masońska jest w swej całości twórczością artystycznie słabą: nie można jednak zapominać, iż walory artystyczne utworów nie odgrywały w związku masońskim takiej roli, jaką przypisuje się im w świecie literackim; w lożach zwracano przede 
wszystkim uwagę na treść i sam fakt powstania utworu. Trzeba również pamiętać, iż utwory te przeważnie dopiero z muzyką tworzyły całość, co lagodziło rygory ich poetyckiej poprawności.

Odrębności zjawiska i problemów poezji masońskiej mogą być interesujące dla studiującego system kulturalne zamkniętych struktur społecznych, ale nie określają one zainteresowań historyka literatıry, a podkreślanie tych odrębności nie stanowi odpowiedzi na pytanie o znaczenie masońskiej poezji w naszej literaturze.

Próbując na to pytanie odpowiedzieć, trzeba zwrócić uwagę, iż poezja masońska powstaje w Polsce w okresie stwarzającym trudności oceny jego znaczenia w historii literatury polskiej. W okresie tym, w pierwszym dwudziestoleciu XIX wieku, nie notujemy wybitnych wydarzeń w zakresie literatury pięknej, a tradycja krytyki romantycznej przekazała nam bardzo surowy osąd stagnacji i maniery ówczesnej produkcji literackiej.

Konstruując dziś historycznoliteracką ocenę tego okresu, podkreśla się znaczenie działalıości kulturalnej poszczególnych instytıcji i środowisk: teatru, salonu, prasy, towarzystw.

Przy braku wybitnych, indywidualnych talentów i nowych stanowisk teoretycznych, działalność ta jest głównym przejawem życia umysłowego, i przypisać jej można szereg konkretnych i pożytecznych osiągnięć.

W płaszczyźnie tak przeprowadzonej oceny, zjawisko poezji masońskiej świadczy o istnieniu jeszcze jednego środowiska rozwijającego działalność kulturalną: środowiska loży masońskiej. W środowisku tym, podobnie jak w teatrze czy salonach, nie powstały wprawdzie wybitne dzicła, ale działalność lóż, jak działalność teatru, prasy itp., dostarczyła produktów tworzących ówczesne życie kulturalne.

Trzeba zwrócić uwagę, iż w porównaniu z okresem Oświecenia, w życiu kulturalnym początków XIX wieku uderzający jest programowo pozaideologiczny charakter prac i dyskusji literackich.

Tylko środowisko masońskie prowadzi poprzez swą poezję propagandę pewnych rozwiązań i postaw ideologicznych.

Problem wpływu tej propagandy na rozwój naszej literatury był już kilkakrotnie podnoszony i wywolal szereg przeciwstawnych ocen. Warto tu chociażby przypomnieć Chrzanowskiego Chleb macierzysty' Ody' do Mtodości i i Stefanii Skwarczyńskiej Mickieu'iczou'ska Hebe jako u'iersz rell'olucyjny.".

Obie prace omawiaja genezę jednego tylko utworu: Ody' do Mtodości, lecz porównanie stanowisk autorów tych prac pozwala na szersze wnioski dotyczące zagadnienia wplywu poezji masońskiej na literaturę polską. 
Ignacy Chrzanowski, operując tekstami poezji masońskiej i Ody do Mtodości, wykazuje icl powinowactwa frazeologiczne, i udowadnia w ten sposób wpływ ideologii masońskiej na genezę utworu Mickiewicza.

Stefania Skwarczyńska wpływy te całkowicie neguje; nie zaprzeczając w zasadzie podobieństwom frazeologicznym, widzi zasadnicze różnice między zachowawczymi walorami ideologii masońskiej a rewolucyjnymi poglądami Mickiewicza.

Kierunek studiowania przede wszystkim relacji miedzy ideologią masoníską a ideologicznymi aspektami rozwoju literatury polskiej od Oświecenia do romantyzmu wydaje się słuszny, ale nie należy ani negować podobieństw frazeologicznych, ani zbyt pochopnie oceniać ideologii masońskiej jako jednoznacznie zachowawczej.

Ideologia masońska w swym zasadniczym zrębie uksztaltowała sį̨ $\mathrm{w}$ drugiej polowie XVIII wieku, i stąd jej koncepcje nie wykraczają poza ramy ideologii określanych jako oświeceniowe. Życie polityczne i literackie końca XVIII wieku dostarczyło wielu okazji nawiązywania do tych idei, toteż w początkach XIX wieku były one traktowane jako juz dobrze znane, a literacki przełom romantyczny spowodowal przesunięcie ich do rzędı idei skostniałych. Czy można jednak uznać, iż w początkach XIX wieku czy nawet już po przełomie romantycznym nastapilo całkowite zanegowanie tych idei, które leżały u podstaw ideologii masońskiej?

Wobec pooświeceniowego wzrostu reakcji katolickiej nie straciła na znaczeniu opozycyjność haseł wolnomularskich wobec ideologii Kościoła. Do takich opozycyjnych haseł zaliczyć należy deistyczną koncepcję Boga, hasło wolności od przesądów i zacofania oraz hasło cnoty traktowanej w miejsce idealistycznych koncepcji sumicnia jako podstawowy i ksztaltowany przez człowieka wyznacznik postępowania i szczęścia ludzkiego.

W zakresie podstawowych problemów społecznych, hasło równości, mimo iż głoszone z pozycji klasowych, ułatwiato awans mieszczaństwa. Poważna rola elementu mieszczańskiego w ostatnich latach działalności polskiego wolnomularstwa wskazuje, iż ideologia masońska doceniała znaczenie tego awansu bardziej niż ideolodzy „szlacheckiego rewolucjonizmu". Wobec wzrastającego znaczenia nierozwiązanej sprawy wolności osobistej, wchodzące wraz z hasłami wolności od przesądów i od przemocy w skład pojęcia masońskiej wolności hasło walki z przemocą jako jeden z warunków wolności pozwalało znaleźć w ideologii masońskiej zachętę do popularnych w późniejszym okresie zapędów narodowo-wyzwoleńczych.

Jak się więc wydaje, podstawowe hasła masońskie, mimo ich związku z koncepcjami oświeceniowymi, nie tracą w początkach XIX wieku pewnej ograniczonej aktualności.

W porównaniu z okresem Oświecenia w początkach XIX wieku odnotować można tylko jedną istotną zmianę waloru haseł głoszonych przez masonerię. W wieku XVIII hasła te były aktywne jako podstawa programów reform, w wieku XIX głoszone były pasywnie, bez ambicji rewolucyjnego czy nawet ewolucyjnego i wcielania ich w życie.

Zmiana ta nie jest jednak zasadnicza w analizie problemów literackich. 
Literatura w możliwościach swego oddziaływania ograniczona jest zawsze do pasywnych form propagandy ideologicznej i może tylko wysuwać postulaty aktywnego działania. Polska poezja masońska, jak i całe wolnomularstwo, postulatów takich nie wysuwała, mimo to jednak propaganda masońskich haseł stwarzała możliwości ich twórczej i postępowej transformacji.

Nurt zwany szlacheckim rewolucjonizmem, którego wpływy tak często odnotowuje się w literaturze drugiego dwudziestolecia XIX wieku, nie tylko nie jest w swych koncepcjach sprzeczny, lecz w niektórych aspektach jest wyraźnie zgodny z hasłami głoszonymi przez poezję masońską w pierwszym dwudziestoleciu.

W rezultacie więc hasła spotykane $\mathrm{w}$ utworach masońskich znajdujemy zarówno w najlepszych tradycjach literatury polskiego Oświecenia, jak i twórczo przeobrażone - w literaturze romantycznej.

Poezja masońska, rozwijając się w okresie dzielącym Oświecenie od romantyzmu, stanowi na gruncie ideologicznym pomost lączący literatury tych okresów, i w pewnej mierze wypełnia lukę, jaką na tym gruncie pozostawila literatura pseudoklasyczna.

Wydaje się, iz w ocenie rozwoju naszej literatury ta cecha masońskiej poezji zasługuje na największą uwagę.

Przypomnieć też trzeba, iż poprzez poezje masońską przenikała do literatury polskiej poezja niemiecka, między innymi Schillera, co miało znaczenie nie tylko w przyswajaniu sobie naszej literaturze poszczególnych utworów czy problemów wersyfikacyjnych, lecz przede wszystkim ulatwiało przenikanie do Polski idei, które, tworząc ducha nowej poezji, stały u podstaw kariery poezji romantycznej.

Warto również podkreślić, iż stając w zasadzie ponad wszelkimi przejawami prądów literackich, poezja masońska wyraża szereg istotnych ideologicznie i intelektualnie problemów, czerpiąc je nie z wzorów literackich, ale z własnych, wewnętrznych tradycji. Wydaje się, iż jest to podstawowa cecha różniąca poezję masońską od równie nieudolnej artystycznie, lecz naśladowczej intelektualnie drugo- czy trzeciorzędnej twórczości literackiej.

Wreszcie, rozważając życie umysłowe omawianego okresu, przypomnieć trzeba szeroki zasięg wpływów wolnomularstwa. Działalność grupki studentów wileńskiego uniwersytetu zaważyła wprawdzie na rozwoju naszej literatury, ale wplyw tej grupy w szczytowych okresach jej działalności był bardzo ograniczony, i wzmocniony został dopiero wielką poezją Mickiewicza. Publiczność salonów, teatru, prasy czy towarzystw była nieliczna i obejmowała tylko wielkie ośrodki kulturalne, natomiast pieśni masońskie śpiewane były w kilkudziesięciu lożach w całym Królestwie i Litwie. Głoszone przez te pieśni hasła nie przyciągnęły wprawdzie do loży Mickiewicza, ale wcisnęły się w umysły tysięcy braci, z których znaczna część nie miała ani szans, ani możliwości uczestniczenia w życiu kulturalnym kraju.

W sumie więc znaczenie w naszej literaturze środowiska masońskiego i jego poezji jest wprawdzie dosyć ułamkowe, ale na określonym historycznie gruncie znaczenie to jest na tyle poważne, iż nakazuje zainteresowanie się poezją masońską w ramach studiów nad rozwojem polskicj literaturyy. 